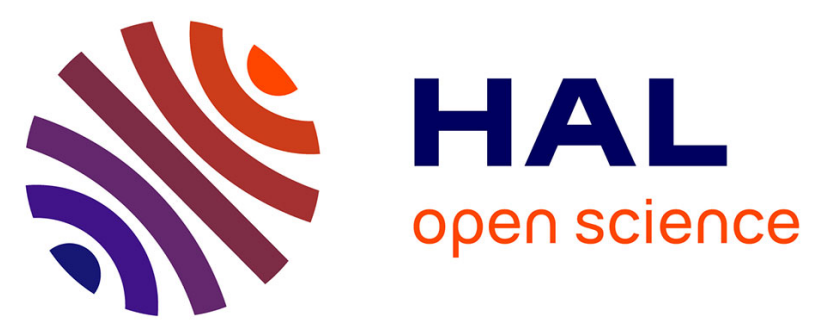

\title{
Size-Exclusion Mechanism Driving Host-Guest Interactions between Octahedral Rhenium Clusters and Cyclodextrins
}

\author{
Anton A Ivanov, Clement Falaise, Kevin Laouer, François Hache, Pascale \\ Changenet, Yuri V Mironov, David Landy, Yann Molard, Stéphane Cordier, \\ Michael A Shestopalov, et al.
}

\section{To cite this version:}

Anton A Ivanov, Clement Falaise, Kevin Laouer, François Hache, Pascale Changenet, et al.. SizeExclusion Mechanism Driving Host-Guest Interactions between Octahedral Rhenium Clusters and Cyclodextrins. Inorganic Chemistry, 2019, 58 (19), pp.13184-13194. 10.1021/acs.inorgchem.9b02048 . hal-02307027

\section{HAL Id: hal-02307027 https://hal-univ-rennes1.archives-ouvertes.fr/hal-02307027}

Submitted on 10 Jan 2021

HAL is a multi-disciplinary open access archive for the deposit and dissemination of scientific research documents, whether they are published or not. The documents may come from teaching and research institutions in France or abroad, or from public or private research centers.
L'archive ouverte pluridisciplinaire HAL, est destinée au dépôt et à la diffusion de documents scientifiques de niveau recherche, publiés ou non, émanant des établissements d'enseignement et de recherche français ou étrangers, des laboratoires publics ou privés. 


\title{
Size-Exclusion Mechanism Driving Host-Guest Interactions between Octahedral Rhenium Clusters and Cyclodextrins.
}

\author{
Anton A. Ivanov, ${ }^{\text {a,b,c }}$ Clément Falaise, ${ }^{\text {a* }}$ Kevin Laouer, ${ }^{\mathrm{d}}$ François Hache, ${ }^{\mathrm{d}}$ Pascale Changenet, ${ }^{\mathrm{d}}$ Yuri V. \\ Mironov, ${ }^{\mathrm{b}, \mathrm{e}}$ David Landy, ${ }^{\mathrm{f}}$ Yann Molard, ${ }^{\mathrm{g}}$ Stéphane Cordier, ${ }^{\mathrm{g}}$ Michael A. Shestopalov, ${ }^{\mathrm{b}, \mathrm{c}, \mathrm{e}}$ Mohamed \\ Haouas $^{\mathrm{a}}$ and Emmanuel Cadot ${ }^{\mathrm{a}}$ \\ ${ }^{a}$ Institut Lavoisier de Versailles, UMR 8180 CNRS, UVSQ, Université Paris-Saclay, Versailles, France. \\ ${ }^{\mathrm{b}}$ Nikolaev Institute of Inorganic Chemistry SB RAS, Novosibirsk, 630090, Russia. \\ c The Federal Research Center of Fundamental and Translational Medicine, Novosibirsk, 630117 Russia \\ ${ }^{d}$ Laboratoire d'Optique et Biosciences, CNRS, INSERM, Ecole Polytechnique, Institut polytechnique de Paris, 91128 Palai- \\ seau, France \\ ${ }^{\mathrm{e}}$ Novosibirsk State University, Novosibirsk, 630090, Russia. \\ ${ }^{\mathrm{f}}$ Unité de Chimie Environnementale et Interactions sur le Vivant, EA 4492, ULCO, Dunkerque, France \\ g Institut des Sciences Chimiques de Rennes, UMR 6226 CNRS, Université de Rennes 1, Rennes, France
}

\begin{abstract}
In aqueous solution, cyclodextrins (CDs) are able to bind strongly either hydrophobic species or also hydrophilic molecules such as octahedral hexametallic cluster. Systematic investigation of the reactivity between native CDs $(\alpha-$ or $\beta-C D)$ and water-soluble rhenium clusters $\left[\operatorname{Re}_{6} \mathrm{Q}_{8}(\mathrm{CN})_{6}\right]^{4-}$ with $\mathrm{Q}=\mathrm{S}$, Se, and Te have been carried out leading to six new crystal structures revealing different types of supramolecular arrangements. Encapsulation of $\left[\mathrm{Re}_{6} \mathrm{Q}_{8}(\mathrm{CN})_{6}\right]^{4-}(\mathrm{Q}=\mathrm{S}$, Se or Te) within two $\beta-\mathrm{CDs}$ is observed regardless of the cluster size. Interestingly, different assembling scenarios are pointed out depending on the host-guest matching featured by no, partial or deep inclusion complexes that involved either primary or secondary rim of the CD tori. In the specific case of $\alpha-C D$, only the smaller cluster $\left[\mathrm{Re}_{6} \mathrm{~S}_{8}(\mathrm{CN})_{6}\right]^{4-}$ is able to form inclusion complex with the tori host. Solution investigations, using a set of complementary techniques including isothermal titration calorimetry (ITC), multinuclear NMR methods, cyclic voltammetry, and electrospray ionization mass spectrometry (ESI-MS), corroborate nicely conclusions of the solid state studies. It appears clearly that size-matching supported by solvent effects play key roles in the stability of the host-guest complexes. At last, circular dichroism studies underline that the chirality induction from cyclodextrins to the rhenium cluster depends strongly on the strength of host-guest interactions.
\end{abstract}

\section{INTRODUCTION}

Cyclodextrins (CDs) represent an attractive class of watersoluble macrocyclic hosts able to trap or encapsulate adapted guest molecules, ${ }^{1}$ that makes them relevant for applications in various domains of industry such as chemical, cosmetics, food or medicine. ${ }^{2-4}$ Native CDs are constituted of six $(\alpha-C D)$, seven $(\beta-C D)$ or eight $(\gamma-C D)$ glucopyranoside units defining semi-flexible toroidal host. Due to the hydrophobic character of their cavity, CDs are known to form robust inclusion complexes with hydrophobic molecules. During decades, the hydrophobic effect and the steric repulsion have been considered as the main contributors to the host-guest association ability of CDs. Nevertheless, recent reports revealed that $\mathrm{CDs}$ can also bind hydrophilic molecules, such as polyoxometalates, ${ }^{5-8}$ metal atoms clusters ${ }^{7,9}$ or dodecaborates. ${ }^{10-12}$ Interestingly, stability of resulting hostguest complexes can approach or even outperform those of conventional adducts built from hydrophobic guests. Such unexpected associations can be understood from solvation properties of the ionic guests described as chaotrope or kosmotrope species according to the Hofmeister classifica- tion. ${ }^{10,13-16}$ Therefore, thermodynamic fingerprint related to supramolecular complexation or adsorption process on surface reveals the chaotropic nature of these polynuclear ions that involve the release of water molecules in the bulk with the concomitant strengthening of hydrogen bonds. Actually, some ionic species has been even identified as "superchaotrope" leading to highly stable supramolecular aggregates with organic matter such as macrocyclic hosts, ${ }^{15,17,18}$ lipid surfaces, ${ }^{19}$ membranes, ${ }^{20}$ or proteins. ${ }^{21-24}$ The control of such self-assembly process recently emerged as an innovative route to hierarchical hybrid supramolecular assemblies. ${ }^{13}$

Octahedral rhenium cluster complexes due to their antitumoral, anti-bacterial, photoluminescent, redox and X-ray contrast properties are appealing inorganic species for applications in biology and medicine. ${ }^{25-35}$ Their encapsulation within biocompatible drug carrier, such as cyclodextrins, represents a promising way to develop biological applications. In context, we demonstrated that clusters $\left[\mathrm{Re}_{6} \mathrm{Q}_{8}(\mathrm{CN})_{6}\right]^{4-}$ (with $\mathrm{Q}=\mathrm{S}$, Se and Te, see Figure 1a-c) interact with $\gamma-\mathrm{CD}$, forming strong host-guest complexes built on cluster embedded within two tori hosts. ${ }^{9}$ 

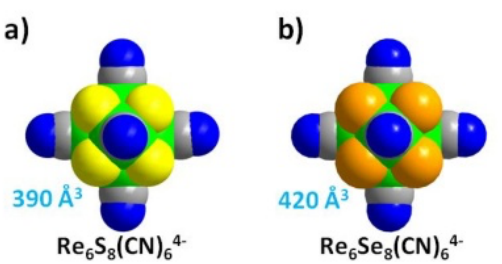

c)

d)

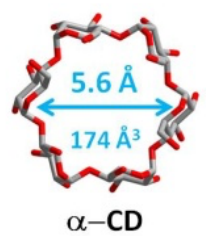

e)

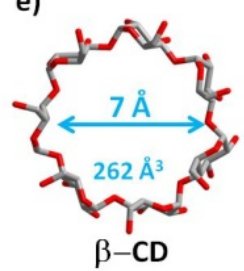

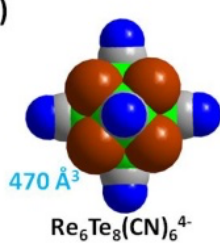

f)

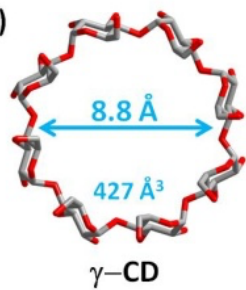

Figure 1: Structural representation of the molecular components used for designing host-guest entities. The inorganic guests are octahedral rhenium clusters $\left[\operatorname{Re}_{6} \mathrm{Q}_{8}(\mathrm{CN})_{6}\right]^{4-}$ with $\mathrm{Q}=\mathrm{S}(\mathrm{a})$, Se (b) and Te (c) built from a $\left\{\mathrm{Re}_{6}\right\}$ core formed by six $\mathrm{Re}^{\mathrm{III}}$ atoms linked through metal-metal bonds. The octahedral $\left\{\operatorname{Re}_{6}\right\}$ core is face capped by eight $\mu_{3}-\mathrm{Q}$ ligands. The coordination sphere of Re centers is completed by cyano ligands in apical positions. The supramolecular hosts are $\alpha-(\mathrm{d}), \beta-(\mathrm{e})$ and $\gamma$-cyclodextrin (f) resulting from the condensation of 6,7 and 8 glucopyranose units, respectively. Colour code: green $=\mathrm{Re}$, yellow $=\mathrm{S}$, orange $=\mathrm{Se}$, brown $=$ $\mathrm{Te}$, grey $=\mathrm{C}$, blue $=\mathrm{N}$, red $=\mathrm{O}$.

Interestingly, the host-guest stability of such inclusion complexes appears strongly influenced by the nature of the inner chalcogenide ligands (Q) and varies significantly in the following order $\mathrm{S}<\mathrm{Se}<\mathrm{Te}$. Surprisingly, this trend of binding hierarchy corresponds to the reverse of chaotropic character of the cluster, meaning that host/guest dispersion energies have also a decisive contribution on the stability of $\left[\mathrm{Re}_{6} \mathrm{Q}_{8}(\mathrm{CN})_{6}\right]^{4-} / \gamma-\mathrm{CD}$ inclusion complexes. Furthermore such behaviour could highlight that the main contributors arising from the solvent could be even more intricate than those simply depicted as chaotrope vs kosmotrope. Based on these conclusions, we hypothesized the possibility to recognize selectively these guest entities with appropriate macrocyclic hosts designed as CDs $(\alpha-, \beta$ - or $\gamma-C D)$.

In this paper, we investigate systematically the effect of cyclodextrin cavity size (Figure 1) on the supramolecular complexation of anionic rhenium clusters $\left[\operatorname{Re}_{6} \mathrm{Q}_{8}(\mathrm{CN})_{6}\right]^{4-}$ in aqueous solution. Six supramolecular assemblies have been successfully isolated as single crystals by slow evaporation or through solvent vapour diffusion. Structural models of $\boldsymbol{\beta}-\mathrm{CD}$ based compounds $\operatorname{Re}_{6} \mathbf{S}_{\mathbf{8}} @ \boldsymbol{\beta}-\mathbf{C D}, \mathbf{R e}_{6} \mathbf{S e}_{\mathbf{8}} @ \boldsymbol{\beta}-\mathbf{C D}$ and $\operatorname{Re}_{6} T_{\mathbf{8}} @ \boldsymbol{\beta}-\mathbf{C D}$ reveal the inclusion of the $\left[\mathrm{Re}_{6} \mathrm{Q}_{8}(\mathrm{CN})_{6}\right]^{4-}$ clusters within two $\beta$-CDs. A distinct scenario is observed with $\alpha-C D$ since only the smaller cluster exhibits a hostguest arrangement, $\mathbf{R e}_{6} \mathbf{S}_{\mathbf{8}} @ \boldsymbol{\alpha}-\mathbf{C D}$. The two larger clusters interact mainly with the outer surface of $\alpha-C D$ as observed in the structure of $\operatorname{Re}_{6} \operatorname{Se}_{8}(\alpha-C D)$ and $\operatorname{Re}_{6} \operatorname{Te}_{8}(\alpha-C D)$. Solution investigations, using a set of complementary techniques (isothermal titration calorimetry, cyclic voltammetry, multinuclear NMR, ESI-MS and circular dichroism) bring valuable insights allowing better understanding about the structure-stability relationship.

These results complement nicely our previous report demonstrating clearly the ability of CDs to recognize selectively rhenium clusters through a size-exclusion mechanism.

\section{EXPERIMENTAL SECTION}

Synthesis: The compounds described herein were synthesized from aqueous mixtures of alpha-cyclodextrin (TCI, 98\%) or beta-cyclodextrin (TCI, 98\%) and $\mathrm{K}_{4}\left[\mathrm{Re}_{6} \mathrm{Q}_{8}(\mathrm{CN})_{6}\right]$ with $\mathrm{Q}=\mathrm{S}$, $\mathrm{Se}$, or Te. The starting chemical reactants were commercially available and were used without any further purification except $\mathrm{K}_{4}\left[\mathrm{Re}_{6} \mathrm{Q}_{8}(\mathrm{CN})_{6}\right]$ compounds which were synthesized as described in literature. ${ }^{36,37}$

$\mathrm{K}_{4}\left\{\left[\operatorname{Re}_{6} \mathrm{~S}_{8}(\mathrm{CN})_{6}\right] @(\boldsymbol{\alpha}-\mathrm{CD})_{2}\right\} \cdot \mathbf{1 5 H}_{2} \mathrm{O}$ noted $\operatorname{Re}_{6} \mathrm{~S}_{\mathbf{8}} @ \boldsymbol{\alpha}-\mathbf{C D}:$ $\mathrm{K}_{4}\left[\operatorname{Re}_{6} \mathrm{~S}_{8}(\mathrm{CN})_{6}\right](0.15 \mathrm{~g} ; 0.089 \mathrm{mmol})$ and $\alpha-\mathrm{CD}(0.259 \mathrm{~g} ; 0.266$ mmol) were dissolved in $2 \mathrm{~mL}$ of deionized (DI) water. The slow evaporation of the resulting solution gave small orange crystals of $\mathbf{R e}_{6} \mathbf{S}_{\mathbf{8}} @ \boldsymbol{\alpha}-\mathbf{C D}$. Yield 0.26 g (75\%) of pure crystalline product. EDS shows $\mathrm{Re}: \mathrm{S}: \mathrm{K}$ ratios $=6.0: 7.8: 3.9$. Anal. Calcd for $\mathrm{C}_{78} \mathrm{H}_{150} \mathrm{~K}_{4} \mathrm{~N}_{6} \mathrm{O}_{75} \mathrm{Re}_{6} \mathrm{~S}_{8}: \mathrm{C}, 23.97 ; \mathrm{H}, 3.87 ; \mathrm{N}, 2.15$. Found: $\mathrm{C}, 23.9 ; \mathrm{H}, 4.0 ; \mathrm{N}, 2.2$. Thermogravimetric analysis revealed a weight loss of about $6.8 \%$ from 50 to $200{ }^{\circ} \mathrm{C}$ (the calculated weight loss of $15 \mathrm{H}_{2} \mathrm{O}$ is $6.9 \%$ ).

$\mathrm{K}_{4}\left[\operatorname{Re}_{6} \mathrm{Se}_{8}(C N)_{6}\right] \cdot(\alpha-C D) \cdot \mathbf{6 H}_{2} \mathrm{O}$ noted $\operatorname{Re}_{6} \operatorname{Se}_{8}(\alpha-C D)$ : $\mathrm{K}_{4}\left[\operatorname{Re}_{6} \mathrm{Se}_{8}(\mathrm{CN})_{6}\right](0.15 \mathrm{~g}, 0.072 \mathrm{mmol})$ and $(0.211 \mathrm{~g}, 0.217$ $\mathrm{mmol})$ of $\alpha-\mathrm{CD}$ were dissolved in $2 \mathrm{~mL}$ of DI water. Crystals of $\operatorname{Re}_{6} \operatorname{Se}_{8}(\alpha-C D)$ were obtained by slow ethanol vapour diffusion into water solution $(10 \mathrm{~mL}$ vessel containing $2 \mathrm{~mL}$ of water solution was placed into a $250 \mathrm{~mL}$ vessel with a tight-fitting lid containing $50 \mathrm{~mL}$ of ethanol) after two days and were collected, washed with water/ethanol mixture and dried on air. Yield 0.148 g $(65 \%)$ of pure crystalline product. EDS shows Re : Se : K ratios $=6.0: 8.2: 4.0$. Anal. Calcd for $\mathrm{C}_{42} \mathrm{H}_{72} \mathrm{~K}_{4} \mathrm{~N}_{6} \mathrm{O}_{36} \mathrm{Re}_{6} \mathrm{Se}_{8}: \mathrm{C}$, 15.98; H, 2.30; N, 2.66. Found: C, 16.1; H, 2.2; N, 2.7. Thermogravimetric analysis revealed a weight loss of about $3.6 \%$ from 50 to $200{ }^{\circ} \mathrm{C}$ (the calculated weight loss of $6 \mathrm{H}_{2} \mathrm{O}$ is $3.4 \%$ ).

$K_{4}\left[\operatorname{Re}_{6} \operatorname{Te}_{8}(C N)_{6}\right] \cdot \mathbf{2}(\alpha-C D) \cdot 20 H_{2} O$ noted $\operatorname{Re}_{6} T_{8}(\alpha-C D)$ : the same procedure was applied as for $\operatorname{Re}_{6} \mathbf{S e}_{\mathbf{8}}(\boldsymbol{\alpha}-\mathbf{C D})$ but using 0.15 $\mathrm{g}(0.061 \mathrm{mmol})$ of $\mathrm{K}_{4}\left[\operatorname{Re}_{6} \mathrm{Te}_{8}(\mathrm{CN})_{6}\right]$ and $0.177 \mathrm{~g}(0.182 \mathrm{mmol})$ of $\alpha-C D$. Yield $0.209 \mathrm{~g}(72 \%)$ of pure crystalline product. EDS shows $\mathrm{Re}: \mathrm{Te}: \mathrm{K}$ ratios $=6.0: 8.0: 4.1$. Anal. Calcd for $\mathrm{C}_{78} \mathrm{H}_{160} \mathrm{~K}_{4} \mathrm{~N}_{6} \mathrm{O}_{80} \mathrm{Re}_{6} \mathrm{Te}_{8}: \mathrm{C}, 19.60 ; \mathrm{H}, 3.38 ; \mathrm{N}, 1.76$. Found: C, $19.4 ; \mathrm{H}, 3.5 ; \mathrm{N}, 1.8$. Thermogravimetric analysis revealed a weight loss of about $7.5 \%$ from 50 to $200{ }^{\circ} \mathrm{C}$ (the calculated weight loss of $20 \mathrm{H}_{2} \mathrm{O}$ is $7.6 \%$ ).

$\mathrm{K}_{4}\left\{\left[\operatorname{Re}_{6} \mathbf{Q}_{8}(\mathbf{C N})_{6}\right] @(\boldsymbol{\beta}-\mathbf{C D})_{2}\right\} \cdot \mathbf{2}(\boldsymbol{\beta}-\mathbf{C D}) \cdot \mathbf{n H}_{2} \mathrm{O}$ with $\mathrm{Q}=\mathrm{S}(\mathrm{n}=$ $25)$, Se $(\mathrm{n}=21)$, or Te $(\mathrm{n}=25)$ noted $\mathbf{R e}_{6} \mathbf{S}_{\mathbf{8}} @ \boldsymbol{\beta}-\mathbf{C D}$, $\mathbf{R e}_{6} \mathbf{S e}_{8} @ \boldsymbol{\beta}-\mathbf{C D}$ and $\mathbf{R e}_{6} \mathbf{T e}_{\mathbf{8}} @ \boldsymbol{\beta}-\mathbf{C D}$ : the same procedure was applied as for $\operatorname{Re}_{\mathbf{6}} \mathbf{S e}_{\mathbf{8}}(\boldsymbol{\alpha}-\mathbf{C D})$ but using $0.074,0.091$ or $0.109 \mathrm{~g}$ $(0.044 \mathrm{mmol})$ of $\mathrm{K}_{4}\left[\operatorname{Re}_{6} \mathrm{Q}_{8}(\mathrm{CN})_{6}\right]$ for $\mathrm{Q}=\mathrm{S}$, Se or Te, respectively, and $0.15 \mathrm{~g}(0.132 \mathrm{mmol})$ of $\beta-\mathrm{CD}$.

$\mathbf{R e}_{6} \mathbf{S}_{\mathbf{8}} @ \boldsymbol{\beta}-\mathbf{C D}$ : Yield $0.171 \mathrm{~g}(58 \%)$ of pure crystalline product. EDS shows Re : $\mathrm{S}: \mathrm{K}$ ratios $=6.0: 8.2: 4.1$. Anal. Calcd for $\mathrm{C}_{174} \mathrm{H}_{330} \mathrm{~K}_{4} \mathrm{~N}_{6} \mathrm{O}_{165} \mathrm{Re}_{6} \mathrm{~S}_{8}: \mathrm{C}, 31.27 ; \mathrm{H}, 4.98 ; \mathrm{N}, 1.26$. Found: C, $31.4 ; \mathrm{H}, 5.0 ; \mathrm{N}, 1.3$. Thermogravimetric analysis revealed a weight loss of about $6.9 \%$ from 50 to $200{ }^{\circ} \mathrm{C}$ (the calculated weight loss of $25 \mathrm{H}_{2} \mathrm{O}$ is $6.8 \%$ ). 
$\mathbf{R e}_{6} \mathbf{S e}_{8} @ \beta-C D$ : Yield 0.169 g (55\%) of pure crystalline product. EDS shows Re : Se : K ratios $=6.0: 7.9: 3.8$. Anal. Calcd for $\mathrm{C}_{174} \mathrm{H}_{322} \mathrm{~K}_{4} \mathrm{~N}_{6} \mathrm{O}_{161} \mathrm{Re}_{6} \mathrm{Se}_{8}: \mathrm{C}, 29.88 ; \mathrm{H}, 4.64 ; \mathrm{N}, 1.20$. Found: $\mathrm{C}$, $30.0 ; \mathrm{H}, 4.5 ; \mathrm{N}, 1.1$. Thermogravimetric analysis revealed a weight loss of about $5.4 \%$ from 50 to $200{ }^{\circ} \mathrm{C}$ (the calculated weight loss of $21 \mathrm{H}_{2} \mathrm{O}$ is $5.4 \%$ ).

$\mathbf{R e}_{6} \mathbf{T e}_{\mathbf{8}} @ \boldsymbol{\beta}-\mathbf{C D}$ : Yield 0.178 g (54\%) of pure crystalline product. EDS shows Re : Te $: \mathrm{K}$ ratios $=6.0: 8.1: 3.9$. Anal. Calcd for $\mathrm{C}_{174} \mathrm{H}_{330} \mathrm{~K}_{4} \mathrm{~N}_{6} \mathrm{O}_{165} \mathrm{Re}_{6} \mathrm{Te}_{8}$ : C, 27.99; H, 4.46; N, 1.13. Found: $\mathrm{C}, 28.0 ; \mathrm{H}, 4.5 ; \mathrm{N}, 1.1$. Thermogravimetric analysis revealed a weight loss of about $6.0 \%$ from 50 to $200{ }^{\circ} \mathrm{C}$ (the calculated weight loss of $25 \mathrm{H}_{2} \mathrm{O}$ is $6.0 \%$ ).

Single Crystal X-ray Diffraction: Crystals of compounds $\operatorname{Re}_{6} S_{8} @ \alpha-C D, \operatorname{Re}_{6} \operatorname{Se}_{8}(\alpha-C D), \operatorname{Re}_{6} T_{2}(\alpha-C D), \operatorname{Re}_{6} S_{8} @ \beta-C D$, $\mathbf{R e}_{6} \mathbf{S e}_{8} @ \beta-C D$ and $\mathbf{R e}_{6} \mathbf{T e}_{8} @ \beta-C D$, were selected under polarizing optical microscope and glued in paratone oil to prevent any loss of crystallization water. X-ray intensity data were collected at low temperature $(\mathrm{T}=200(2) \mathrm{K})$ on a Bruker X8 APEX2 with a CCD area detector using Mo $\mathrm{K}_{\alpha}$ radiation $(\lambda=0.71073 \AA)$. Data reduction was accomplished using SAINT V7.53a. The substantial redundancy in data allowed a semi-empirical absorption correction (SADABS V2.10) to be applied, on the basis of multiple measurements of equivalent reflections. Using Olex 2,38 the structure was solved with the ShelXT ${ }^{39}$ structure solution program using Intrinsic Phasing and refined with the ShelXL ${ }^{40}$ refinement package using Least Squares minimization. The remaining non-hydrogen atoms were located from Fourier differences and were refined with anisotropic thermal parameters. Positions of the hydrogen atoms belonging to the cyclodextrins were calculated. In the compounds exhibiting host-guest inclusion complexes $\mathbf{R e}_{6} \mathbf{S}_{\mathbf{8}} @ \boldsymbol{\alpha}-\mathbf{C D}, \mathbf{R e}_{6} \mathbf{S}_{\mathbf{8}} @ \boldsymbol{\beta}-\mathbf{C D}, \mathbf{R e}_{6} \mathbf{S e}_{\mathbf{8}} @ \boldsymbol{\beta}-\mathbf{C D}$ and $\mathbf{R e}_{6} \mathbf{T e}_{\mathbf{8}} @ \boldsymbol{\beta}-\mathbf{C D}$, the cluster is disordered over two positions. Crystallographic data for single-crystal X-ray diffraction studies are summarized in Table S1 and Table S2 for compounds based on $\alpha-C D$ and $\beta-C D$, respectively. CIF files can be obtained free of charge from the Cambridge Crystallographic Data Centre via https://www.ccdc.cam.ac.uk. Deposit number: 1905524 for $\mathbf{R e}_{6} \mathbf{S}_{\mathbf{8}} @ \boldsymbol{\alpha}-\mathbf{C D}, \quad 1905525$ for $\mathbf{R e}_{6} \mathbf{S e}_{\mathbf{8}}(\boldsymbol{\alpha}-\mathbf{C D}), 1905526$ for $\mathbf{R e}_{6} \mathbf{T e}_{8}(\boldsymbol{\alpha}-\mathbf{C D}), 1905527$ for $\mathbf{R e}_{6} \mathbf{S}_{\mathbf{8}} @ \boldsymbol{\beta}-\mathbf{C D}, 1905528$ for $\mathbf{R e}_{6} \mathbf{S e}_{8} @ \boldsymbol{\beta}-\mathbf{C D}$ and 1905529 for $\mathbf{R e}_{6} \mathbf{T} \mathbf{e}_{8} @ \boldsymbol{\beta}-\mathbf{C D}$.

NMR studies. All NMR spectra were measured in $\mathrm{D}_{2} \mathrm{O}$ at $27^{\circ} \mathrm{C}$. ${ }^{77} \mathrm{Se}$ and ${ }^{125} \mathrm{Te}$ NMR spectra were measured on a Bruker Avance 400 spectrometer at Larmor frequencies of 76.3 and $126.3 \mathrm{MHz}$, using $\mathrm{H}_{2} \mathrm{SeO}_{3}$ in alkaline solution (1272.6 ppm) and aqueous $\mathrm{H}_{6} \mathrm{TeO}_{6}(713 \mathrm{ppm})$ as external secondary references, respectively. ${ }^{1} \mathrm{H}$ NMR spectra were recorded on a $300 \mathrm{MHz}$ spectrometer. Chemical shifts were referenced to tetramethylsilane (TMS).

ITC. Formation constants and inclusion enthalpies were simultaneously determined for each system by the use of an isothermal calorimeter (ITC200, MicroCal Inc., USA), at three temperatures $(283,298$ and $313 \mathrm{~K})$. See Supporting Information for further details.

Electrochemistry. Cyclic voltammetric (CV) experiments were carried out with a Methrom Autolab PGSTAT230 driven by a computer using NOVA software. Measurements were performed at room temperature in a conventional single compartment cell. A glassy carbon (GC) electrode with a diameter of $3 \mathrm{~mm}$ was used as the working electrode. The auxiliary electrode was a Pt plate and potentials are quoted against a saturated calomel electrode (SCE). The solutions were deaerated thoroughly for at least 10 minutes with pure argon. The solution was prepared by dissolving $0.01 \mathrm{mmol}$ of metal cluster in $20 \mathrm{~mL}$ of aqueous solution of $2.5 \mathrm{mM} \mathrm{HClO}_{4}$. Then different amounts of cyclodextrin have been added under stirring.

Electrospray Ionization Mass Spectrometry (ESI-MS). Electrospray ionization mass spectra were collected using a Q-TOF instrument supplied by WATERS. Samples were dissolved in water at a concentration of $1 \mathrm{~g} / \mathrm{L}$ (based on metal cluster) and were introduced into the spectrometer via an ACQUITY UPLC WATERS system whilst a Leucine Enkephalin solution was coinjected via a micro pump as internal standard.

Circular dichroism. Circular dichroism spectra were recorded in the range 200-350 $\mathrm{nm}$ with a home-made spectropolarimeter. The basic principle relies on direct measurements of the CD signals corresponding to the differential absorbance between left- and right-circularly polarized light: $C D=A_{L}-A_{R}$.

To this end, fast modulation of the light was achieved by a photo-elastic modulator coupled with a phase sensitive detection. $\mathrm{CD}$ investigations have been carried out on solutions containing large excess of CDs (100 mM for $\alpha-$ and $\gamma-C D$, and $14 \mathrm{mM}$ for $\beta-C D)$. For these measurements, the sample absorbance was adjusted to about 1 (for $1 \mathrm{~mm}$ optical path) at the absorption maximum. The cluster concentration was fixed at $0.3,0.18$ and $0.06 \mathrm{mM}$ for S-, Se- and Te- derivatives, respectively. The CD signals can be also correlated to the sample ellipticity $\theta$ expressed in degrees, as follow: $\theta \sim 32.9 \times\left(A_{L}-A_{R}\right)$.

Infrared spectroscopy. Fourier Transform Infrared (FT-IR) spectra were recorded on a 6700 FT-IR Nicolet spectrophotometer, using diamond ATR technique. The spectra were recorded on non-diluted compounds in the range $400-4000 \mathrm{~cm}^{-1}$. The IR spectra are provided in Supporting Information (see Figs. S1-2).

Energy-Dispersive X-ray Spectroscopy. EDS measurements were performed using a SEM-FEG (Scanning Electron Microscope enhanced by a Field Emission Gun) equipment (JSM 7001-F, Jeol). The measurements were acquired with a SDD XMax $50 \mathrm{~mm}^{2}$ detector and the Aztec (Oxford) system working at $15 \mathrm{kV}$ and $10 \mathrm{~mm}$ distance. The quantification is realized with the standard library provided by the constructor using $\mathrm{L}_{\alpha}$ lines.

\section{RESULTS and DISCUSSION}

\section{Synthesis of supramolecular hybrid compounds}

The supramolecular hybrid compounds constructed from octahedral rhenium clusters $\left[\operatorname{Re}_{6} \mathrm{Q}_{8}(\mathrm{CN})_{6}\right]^{4-}(\mathrm{Q}=\mathrm{S}$, Se, Te $)$ and cyclodextrins have been systematically isolated from aqueous mixtures containing water-soluble rhenium clusters $\mathrm{K}_{4}\left[\mathrm{Re}_{6} \mathrm{Q}_{8}(\mathrm{CN})_{6}\right]$ with three equivalents of CD. Crystals of $\mathbf{R e}_{6} \mathbf{S}_{8} @ \boldsymbol{\alpha}-\mathbf{C D}$ were obtained by slow evaporation, while single crystals of $\operatorname{Re}_{6} \operatorname{Se}_{8}(\alpha-C D)$ and $\operatorname{Re}_{6} \mathbf{T e}_{8}(\alpha-C D)$ were obtained by ethanol vapour diffusion. To avoid crystallization of $\beta-C D$ which exhibits low solubility in water, the isolation of $\operatorname{Re}_{6} \mathrm{~S}_{\mathbf{8}} @ \boldsymbol{\beta}-\mathbf{C D}, \quad \operatorname{Re}_{6} \mathrm{Se}_{\mathbf{8}} @ \boldsymbol{\beta}-\mathbf{C D} \quad$ and $\mathbf{R e}_{6} \mathbf{T e}_{\mathbf{8}} @ \boldsymbol{\beta}-\mathbf{C D}$ have been performed also by ethanol vapour diffusion. The composition of all compounds has been established by different complementary techniques (elemental 
analysis, EDS, IR and TGA) in accordance with the singlecrystal X-ray diffraction analysis.

\section{Structure description of supramolecular hybrid compounds}

$\operatorname{Re}_{6} \mathbf{S}_{\mathbf{8}} @ \boldsymbol{\alpha}-\mathbf{C D}$ crystallizes in the non-centrosymmetric space group $C_{2}$ and its structure contains two crystallographically independent rhenium clusters which are encapsulated into two $\alpha$-CDs (Figure 2a). In this host-guest assembly, the secondary face of $\alpha-C D$ interacts with the inorganic guest, which has been previously observed between $\gamma-\mathrm{CD}$ and the clusters $\left[\operatorname{Re}_{6} \mathrm{Q}_{8}(\mathrm{CN})_{6}\right]^{4-}$ with $\mathrm{Q}=\mathrm{Se}$ and Te. ${ }^{9}$ The equatorial plan of octahedral clusters $\left[\operatorname{Re}_{6} \mathrm{~S}_{8}(\mathrm{CN})_{6}\right]^{4-}$ lined by four cyano groups is parallel to $\alpha-\mathrm{CDs}$, and the two other cyano groups point to the centre of both symmetric host cavities. This host-guest organization induces supramolecular stabilization through numerous hydrogen bonds. The four equatorial cyano groups contribute to the supramolecular stabilization through hydrogen bonding with their closest hydroxyl groups of the secondary face, giving an average $\mathrm{N} \bullet \bullet \mathrm{H}-\mathrm{O}$ distance of $3.04 \AA$. In addition, each inner ligand, herein sulphur, interacts weakly with the hydrogen atoms commonly named H-3 (see Figure 6 for $\mathrm{H}$ labelling) with distances range $\mathrm{C}-\mathrm{H} \bullet \bullet \mathrm{S}=2.6-2.9 \AA$. a)

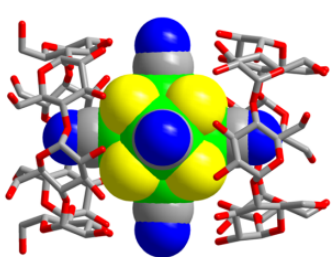

b)

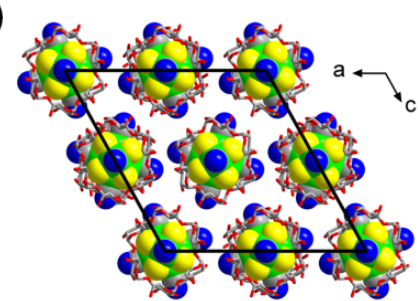

Figure 2: Mixed representations of the solid state structure of compound $\mathrm{Re}_{6} \mathrm{~S}_{8} @ \alpha-\mathrm{CD}$ containing the $\left[\mathrm{Re}_{6} \mathrm{~S}_{8}(\mathrm{CN})_{6}\right]^{4-}$ anion and $\alpha-C D$. a) Supramolecular discrete host-guest arrangement showing two secondary faces embedding the rhenium-sulphide cluster; b) view of the unit cell highlighting the packing of the inclusion complexes along the $\mathrm{b}$ axis. Counter cations $\left(\mathrm{K}^{+}\right)$, hydrogen atoms of $\alpha$ $\mathrm{CD}$ and free water molecules were omitted for clarity.

Interestingly, within this supramolecular adduct, the shortest distance between two hydroxyls of distinct CD is around 5.8 $\AA$, indicating the absence of interactions between the CDs. This configuration strongly differs from the host-guest adducts involving $\gamma-\mathrm{CDs}$ and $\left[\mathrm{Re}_{6} \mathrm{Q}_{8}(\mathrm{CN})_{6}\right]^{4-}$ with $\mathrm{Q}=\mathrm{Se}$ and $\mathrm{Te}$, where numerous H-bonds were observed between the two $\gamma$-CDs, favouring the supramolecular stabilization. ${ }^{9}$ In the crystal packing of $\mathbf{R e}_{6} \mathbf{S}_{\mathbf{8}} @ \boldsymbol{\alpha}-\mathbf{C D}$, two host-guest entities $\left\{\left[\operatorname{Re}_{6} \mathrm{~S}_{8}(\mathrm{CN})_{6}\right] @(\alpha-\mathrm{CD})_{2}\right\}^{4-}$ are stacked together through their primary faces along the $b$ axis giving the typical bamboo-like arrangement (Figure 2b). The 3D cohesion is ensured by the counter cations, potassium ions, which are located between the tubules.

$\operatorname{Re}_{6} \operatorname{Se}_{8}(\boldsymbol{\alpha}-\mathbf{C D})$ crystallizes in the space group $P 2{ }_{1}$ and its structure contains one crystallographically independent rhenium cluster and one $\alpha-C D$. The crystal structure of $\operatorname{Re}_{6} \mathbf{S e}_{8}(\boldsymbol{\alpha}-\mathbf{C D})$ differs from $\operatorname{Re}_{6} \mathbf{S}_{\mathbf{8}} @ \boldsymbol{\alpha}-\mathbf{C D}$ and results rather from a co-crystallization process between $\mathrm{CD}$ and cluster without formation of host-guest complexes. Then, $\left[\operatorname{Re}_{6} \mathrm{Se}_{8}(\mathrm{CN})_{6}\right]^{4-}$ clusters are almost located in the centre of rectangle defined by four $\alpha-C D$ s oriented in the $(b c)$ plane (Figure $3 \mathrm{a}$ and $3 \mathrm{~b}$ ). The $C_{3}$ axis of the octahedral metal cluster is parallel with the central $\alpha-\mathrm{CD}$ axis. In such arrangement, clusters interact weakly with the outer wall of $\alpha$-CDs. Besides, three cyano groups participate to the network stabilization through three hydrogen bonds with closest hydroxyl of the primary face, giving $\mathrm{N} \bullet-\mathrm{O}$ distances in the $2.75-3.04$ $\AA$ range. These weak interactions between the cluster units and $\alpha-C D$ s promote the formation of $2 \mathrm{D}$ extended hybrid organic-inorganic layers. The $3 \mathrm{D}$ cohesion is then ensured by the cations, potassium ions found between the $2 \mathrm{D}$ anionic planes.

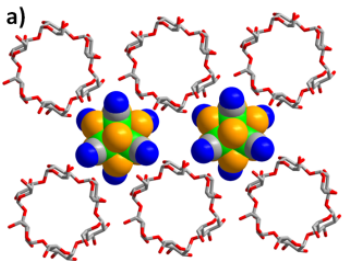

b)

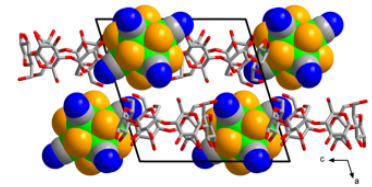

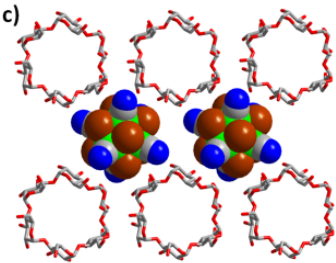

d)

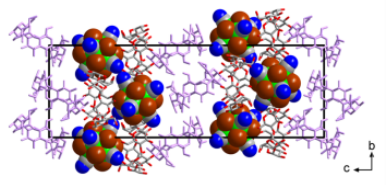

Figure 3: View of the structure of $\operatorname{Re}_{6} \mathbf{S e}_{8}(\alpha-\mathbf{C D})$ and $\operatorname{Re}_{6} \operatorname{Te}_{8}(\alpha-C D)$. Each cluster interacts with the outer surface of the $\alpha-C D$. This arrangement involves the formation of supramolecular 2D-sheet in the $b c$ plane for $\operatorname{Re}_{6} \mathbf{S e}_{8}(\boldsymbol{\alpha}-\mathbf{C D})$ (a) and in the $a b$ plane for $\operatorname{Re}_{6} \operatorname{Te}_{8}(\alpha-C D)(c)$. b) View of the unit cell of $\operatorname{Re}_{6} \operatorname{Se}_{8}(\alpha-C D)$ highlighting the stacking of supramolecular sheet along the perpendicular direction to the $b c$ plane. d) View of the unit cell of $\operatorname{Re}_{6} \operatorname{Te}_{8}(\alpha-C D)$ showing the supramolecular organization resulting from the assembly of two types of layers perpendicular to the $c$ direction: a hybrid layer containing two 2D-sheets and a layer of free $\alpha-\mathrm{CDs}$ (CD in purple). Counter cations $\left(\mathrm{K}^{+}\right)$, hydrogen atoms of $\alpha-C D$ and free water molecules were omitted for clarity.

$\operatorname{Re}_{\mathbf{6}} \mathbf{T e}_{\mathbf{8}}(\boldsymbol{\alpha}-\mathbf{C D})$ crystallizes in the space group $P 2{ }_{1} 2_{1} 2_{1}$ and its structure contains one crystallographically independent rhenium cluster and two independent $\alpha$-CDs. The environment of the tellurium containing cluster is similar to that observed in the compound $\operatorname{Re}_{6} \mathbf{S e}_{8}(\boldsymbol{\alpha}-\mathbf{C D})$ where the tellurium cluster is also surrounded by four $\alpha-$ CDs which delimit a rectangle (Figure 3c). The dimensions of this rectangle are slightly bigger than that found in the compound $\operatorname{Re}_{6} \operatorname{Se}_{8}(\boldsymbol{\alpha}-\mathbf{C D})\left(13.7 \times 18.7 \AA\right.$ for $\operatorname{Re}_{6} \operatorname{Te}_{8}(\boldsymbol{\alpha}-\mathbf{C D})$ and $14.1 \times$ $17.5 \AA$ for $\left.\operatorname{Re}_{6} \operatorname{Se}_{\mathbf{8}}(\boldsymbol{\alpha}-\mathbf{C D})\right)$. This is due to a slight deviation of the $\mathrm{C}_{3}$ axis of tellurium-containing clusters from the central $\mathrm{CD}$ axis (Figure 3c). Four cyano groups of each $\left[\operatorname{Re}_{6} \mathrm{Te}_{8}(\mathrm{CN})_{6}\right]^{4-}$ interact with the outer wall of the macrocyclic host through hydrogen bonds. The stronger ones are observed between two cyano groups and closest hydroxyl of the secondary face, giving $\mathrm{N} \bullet \bullet \mathrm{O}$ distances of $2.72 \AA$. Two additional weakest hydrogen bonds involving cyano groups and hydroxyl group of primary faces $(\mathrm{N} \bullet \bullet \mathrm{O}=3.1 \AA)$ contribute further to the stabilization of the supramolecular network. These overall weak interactions between the $\left[\operatorname{Re}_{6} \mathrm{Te}_{8}(\mathrm{CN})_{6}\right]^{4-}$ and $\alpha-\mathrm{CDs}$ allow the formation of anionic 2D-sheet in the $a b$ plane (Figure 3d). Two hybrid 2D-sheets 
stack together through primary faces of $\mathrm{CD}$, resulting in the formation of a hybrid 'double layer'. In the 3D arrangement, this hybrid "double layer" alternates with a cluster-free CD layer generating a lamellar assembly stacked along the [001] direction (Figure 3d). The electric balance is ensured by the presence of potassium ions spanning CDs and cyano groups of clusters. a)

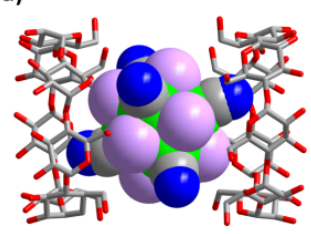

b)

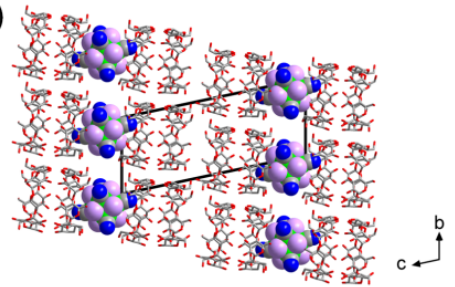

Figure 4: Views of the structural arrangement in the series $\mathrm{K}_{4}\left\{\left[\mathrm{Re}_{6} \mathrm{Q}_{8}(\mathrm{CN})_{6}\right] @(\beta-\mathrm{CD})_{2}\right\} \cdot 2(\beta-\mathrm{CD}) \cdot \mathrm{nH}_{2} \mathrm{O} \quad$ with $\mathrm{Q}=\mathrm{S}$ $\left(\operatorname{Re}_{6} \mathbf{S}_{8} @ \beta-C D\right), S e\left(\operatorname{Re}_{6} \mathbf{S e}_{8} @ \beta-C D\right)$ and Te $\left(\operatorname{Re}_{6} \operatorname{Te}_{8} @ \beta-C D\right)$. a) View of the rhenium cluster partially embedded within two $\beta$-CDs exposing their primary faces. b) View of the unit cell and the stacking of the supramolecular sheet along the perpendicular direction to the $b c$ plane.

Compounds $\quad \operatorname{Re}_{6} \mathrm{~S}_{8} @ \beta-C D, \quad \operatorname{Re}_{6} \mathrm{Se}_{8} @ \beta-C D \quad$ and $\operatorname{Re}_{6} T_{\mathbf{8}} @ \boldsymbol{\beta}-\mathbf{C D}$. Structural analysis of $\mathrm{K}_{4}\left\{\left[\mathrm{Re}_{6} \mathrm{Q}_{8}(\mathrm{CN})_{6}\right] @(\beta-\mathrm{CD})_{2}\right\} \cdot 2(\beta-\mathrm{CD}) \cdot \mathrm{nH}_{2} \mathrm{O}$ with $\mathrm{Q}=\mathrm{S}(\mathrm{n}$ $=25)$, Se $(n=21)$, and Te $(n=25)$ (noted $\mathbf{R e}_{6} \mathbf{S}_{\mathbf{8}} @ \boldsymbol{\beta}-\mathbf{C D}$, $\operatorname{Re}_{6} \mathrm{Se}_{8} @ \boldsymbol{\beta}-\mathrm{CD}$ and $\mathbf{R e}_{6} \mathrm{Te}_{\mathbf{8}} @ \boldsymbol{\beta}-\mathbf{C D}$, respectively) reveals three isostructural compounds which contain the octahedral cluster $\left[\operatorname{Re}_{6} \mathrm{Q}_{8}(\mathrm{CN})_{6}\right]^{4-}$ embedded into two $\beta-\mathrm{CDs}$ (Figure $4 a)$. This host-guest arrangement is different from the supramolecular inclusion complex previously observed with $\alpha-C D$ and $\left[\mathrm{Re}_{6} \mathrm{~S}_{8}(C N)_{6}\right]^{4-}$. In fact, the $\left[\mathrm{Re}_{6} \mathrm{Q}_{8}(\mathrm{CN})_{6}\right]^{4-}$ interacts with the primary face instead of the larger rim (secondary face) of the cyclodextrins. The $C_{4}$ axis of the octahedral cluster deviates significantly from the $\beta-\mathrm{CD}$ central axis $\left(23^{\circ}\right)$. Consequently, the four equatorial cyano groups, sandwiched between both primary faces, interact non-equally with proximal H6 protons $(\mathrm{N} \cdots \mathrm{C}=2.8-3.0 \AA)$. The two resulting cyano groups pointed to the host cavities slightly interact with the inner tori host $(\mathrm{N} \bullet \bullet \mathrm{H}-\mathrm{C}=3.0-3.2 \AA)$. In the crystal packing, the inclusion complex $\left\{\left[\operatorname{Re}_{6} \mathrm{Q}_{8}(\mathrm{CN})_{6}\right] @(\beta-\mathrm{CD})_{2}\right\}^{4-}$ is stacked with two empty $\beta$ CDs through their secondary faces along [011] direction, giving a $0 D$ tubular arrangement (Figure 4b). The cohesion within such supramolecular organization is mainly ensured by a network of hydrogen bonding that interconnects secondary faces of $\beta$-CDs $(\mathrm{O} \bullet \bullet \mathrm{O}=2.7-3.2 \AA)$ giving bamboo like tubular arrangement. In addition to this hydrogen bonding network, potassium cations and water molecules are found between the tubular arrangements.

Summary of the host-guest structural features. The nature of the supramolecular arrangements built from cyclodextrins and rhenium based clusters depends on the size-matching between the macrocyclic host and the inorganic cluster. The types of inclusion complexes observed in solid state are summarized in Figure 5. The solid-state studies clearly indicate the $\left[\mathrm{Re}_{6} \mathrm{Se}_{8}(\mathrm{CN})_{6}\right]^{4-}$ and $\left[\mathrm{Re}_{6} \mathrm{Te}_{8}(\mathrm{CN})_{6}\right]^{4-}$ interact similarly with $\mathrm{CDs}$ while $\left[\mathrm{Re}_{6} \mathrm{~S}_{8}(\mathrm{CN})_{6}\right]^{4-}$ shows a distinct behav- iour. In our previous study, ${ }^{9}$ we showed that rhenium based clusters interact strongly with $\gamma-\mathrm{CD}$ giving preferentially $1: 2$ supramolecular assemblies where the smaller cluster $(Q=S)$, interacts with the primary faces of tori host, while the larger ones $(\mathrm{Q}=\mathrm{Se}$ or $\mathrm{Te})$ are deeply embedded through the secondary faces. Sulphur containing cluster also interacts differently with $\alpha-C D$ than the larger clusters. Actually, we showed the smaller $\alpha-\mathrm{CD}$ gives host-guest system exclusively with $\left[\mathrm{Re}_{6} \mathrm{~S}_{8}(\mathrm{CN})_{6}\right]^{4-}$ through the secondary rim. From this observation, it appears clearly that Se and Te based clusters are too large to be embedded into the cavity of the $\alpha-C D$. In the case of $\beta-C D$, all clusters adopt the same structural arrangement consisting with a host-guest arrangement involving a cluster unit and two CDs. In conclusion, we evidence the high propensity of the rhenium clusters $\left[\mathrm{Re}_{6} \mathrm{Q}_{8}(\mathrm{CN})_{6}\right]^{4-}$ and CDs to form hybrid networks. Depending on sizematching criteria, these networks result either from cocrystallization processes or from 1:2 inclusion complexes.

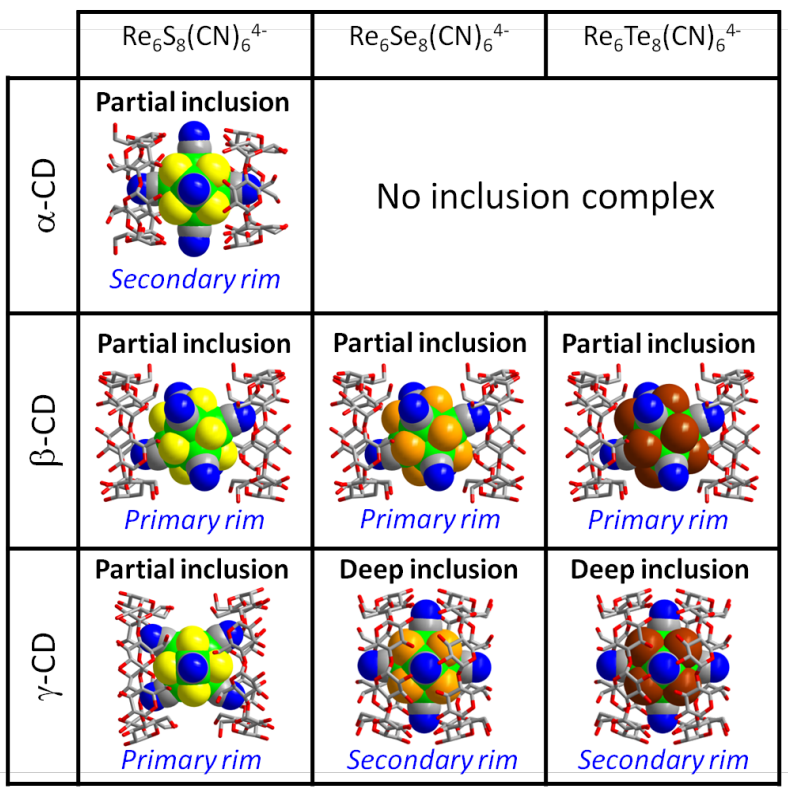

Figure 5: Summary of the structural arrangements of $\left[\operatorname{Re}_{6} Q_{8}(C N)_{6}\right]^{4-}(Q=$ $\mathrm{S}$, Se or Te) with $\alpha-, \beta-$ and $\gamma-\mathrm{CDs}$ observed in solid state.

\section{Solution studies}

To get more insights within the supramolecular behaviour of cluster-CD system, solution studies of aqueous mixtures have been carried out using a set of complementary techniques including multinuclear NMR spectroscopy, ITC, cyclic voltammetry, ESI-MS spectrometry and circular dichroism.

NMR spectroscopy. The interaction of clusters $\left[\operatorname{Re}_{6} \mathrm{Q}_{8}(\mathrm{CN})_{6}\right]^{4-}(\mathrm{Q}=\mathrm{S}, \mathrm{Se}$ or Te $)$ with the $\alpha-$ and $\beta-\mathrm{CD}$ has been investigated by ${ }^{1} \mathrm{H}$ NMR titrations up to 4 equivalents of cluster per cyclodextrin (Figures S3-S8). Figure 6 compares the resulting end-point titration spectra obtained for the different CDs in presence of 4 equivalents of cluster. This analytical tool is sensitive enough to get insight about the nature of supramolecular interactions. It is worth to be mentioned that the NMR titration experiments show gradual variations of the ${ }^{1} \mathrm{H}$ resonances depending on the ratio 


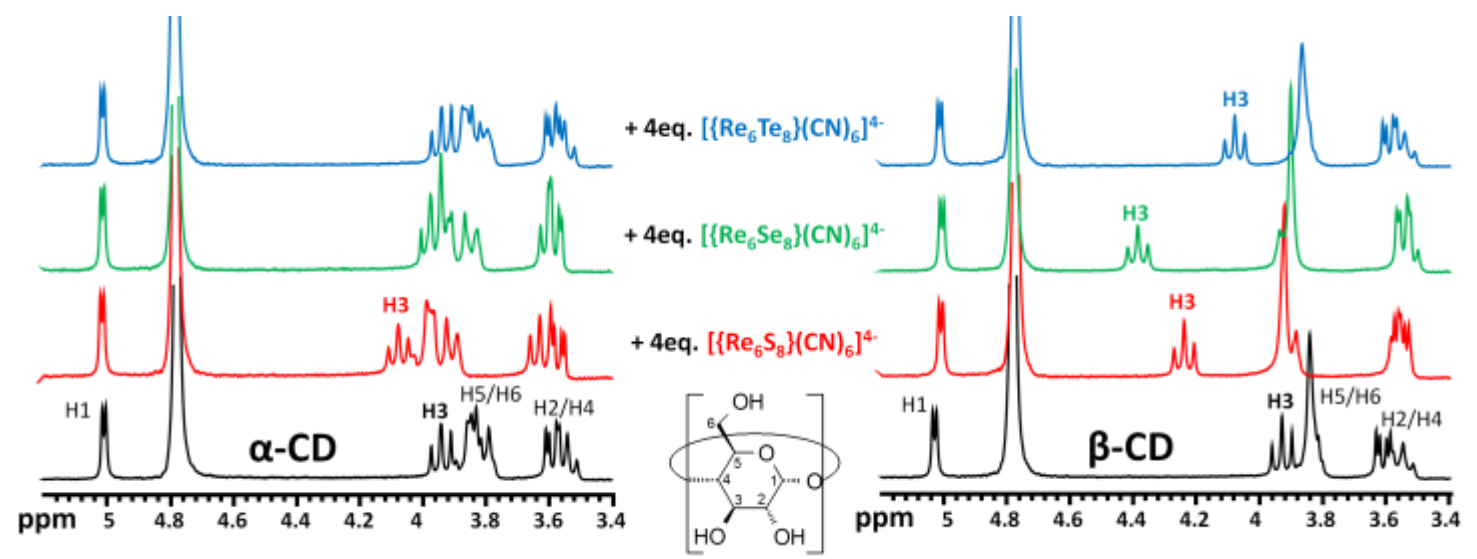

Figure 6. ${ }^{1} \mathrm{H}$ NMR spectra of $\alpha$ - (left) and $\beta-\mathrm{CD}$ (right) with four equivalents of octahedral rhenium cluster $\left[\mathrm{Re}_{6} \mathrm{Q}_{8}(\mathrm{CN})_{6}\right]^{4-}\left(\mathrm{Q}=\mathrm{S}, \mathrm{Se}\right.$ or Te) in $\mathrm{D}_{2} \mathrm{O}$. Concentration of organic host is fixed to $2 \mathrm{mM}$.

cluster/CD (see Figure S3-S8). This features fast exchange on the NMR time scale consistent with labile host-guest associations. Evolution of ${ }^{1} \mathrm{H}$ NMR spectrum in presence of four equivalents of cluster reveals contrasted behaviours related to the host-guest size-matching (see Figure 6).

In the case of $\alpha-C D$, only tiny modifications of the organic host NMR signals are detected in presence of four equivalents of $\left[\mathrm{Re}_{6} \mathrm{Se}_{8}(\mathrm{CN})_{6}\right]^{4-}$ or $\left[\mathrm{Re}_{6} \mathrm{Te}_{8}(\mathrm{CN})_{6}\right]^{4-}$, consistent with very weak interactions. The situation differs for the sulphurcontaining cluster $\left[\mathrm{Re}_{6} \mathrm{~S}_{8}(\mathrm{CN})_{6}\right]^{4-}$ showing a significant downfield shift for the protons H3, H5 and H6 in accordance with formation of host-guest complexes.

Besides, the ${ }^{1} \mathrm{H}$ NMR spectra of $\beta-\mathrm{CD}$ upon increasing concentration of all the clusters revealed continuous changes of chemical shifts (see Figure 6 and Supporting Information, Figures S6-S8). This observation suggests that all clusters interact with $\beta-\mathrm{CD}$ to give labile associations involved in fast chemical exchange regime. The most significantly affected chemical shift corresponds to the inner proton $\mathrm{H} 3$, and the shift amplitude increases in the following order $\mathrm{Te}<\mathrm{S}<$ Se, which could be the fingerprint of a selective sizematching process. For instance, in presence of four cluster equivalents, the difference in chemical shift is $0.35,0.5$, and $0.2 \mathrm{ppm}$ for S-, Se- and Te-derivative, respectively. These results would indicate predominant host-guest associations in solution occurring preferentially with the secondary face of the torus. However, the small downfield shifts of the proton $\mathrm{H} 5$ and $\mathrm{H} 6$ are also observed, that would indicate that these clusters are able to interact also with the primary face of $\beta-C D$. These undergoing changes in solution are probably due to versatile behaviour arising from close binding energies between primary and secondary rims of the $\beta-C D$.

All these ${ }^{1} \mathrm{H}$ NMR observations corroborate quite well conclusions arising from structural investigations: i) only the sulphur-containing cluster forms inclusion complexes with $\alpha-C D$ in solution, and ii) all clusters interact with the $\beta$-cavity in solution to give inclusion complexes. However, we observe some apparent discrepancies between crystal structures analysis and behaviours in solution. For instance, the clusters interact with the primary face of $\beta-$ CDs in solid state, while NMR solution investigation indicates clusters are mainly interacting with the secondary face through the $\mathrm{H} 3$ protons. Such an observation is rather consistent with close binding energies that favour interactions with secondary or primary faces depending either on the minimization of lattice energy in the solid state or on the solvent effect in solution.

${ }^{77} \mathrm{Se}$ and ${ }^{125} \mathrm{Te}$ NMR experiments have been carried out (Figures S9-S10). Tiny variation of the ${ }^{125} \mathrm{Te}$ NMR resonance $(\Delta \delta<0.5 \mathrm{ppm})$ is consistent with weak interactions between $\left[\operatorname{Re}_{6} \mathrm{Te}_{8}(\mathrm{CN})_{6}\right]^{4-}$ and $\beta-\mathrm{CD}$. Such situation differs significantly from $\gamma-\mathrm{CD}$ showing the deep embedment of the Teclusters inside $\gamma-\mathrm{CD}$ cavity. ${ }^{9}$ Besides, $\left[\mathrm{Re}_{6} \mathrm{Se}_{8}(\mathrm{CN})_{6}\right]^{4-}$ cluster undergoes a 4 ppm downfield shift of the ${ }^{77} \mathrm{Se}$ NMR resonance in presence of $\beta-C D$ that highlights stronger supramolecular interactions. It is worth noting that about 4 ppm upfield shift in the ${ }^{77} \mathrm{Se}$ NMR was observed with $\gamma-\mathrm{CD} .{ }^{9}$ This opposite trend in the ${ }^{77} \mathrm{Se}$ NMR spectra highlights probably different scenario in host-guest binding modes (i.e. partial versus deep encapsulation or primary versus secondary or 1:1 versus 1:2 complex type).

\section{Isothermal Titration Calorimetry.}

ITC investigations have been carried out to determine the thermodynamic parameters of the supramolecular complexation processes. The binding constants and changes of enthalpy $\Delta_{\mathrm{r}} \mathrm{H}^{*}$ and entropy $\Delta_{\mathrm{r}} \mathrm{S} *$ of each cluster/CD system are given in Table 1, and compared to data previously obtained with the $\left[\operatorname{Re}_{6} \mathrm{Q}_{8}(\mathrm{CN})_{6}\right]^{4-} / \gamma-\mathrm{CD}$ system. ${ }^{9}$ ITC thermograms and isotherms are presented in Supporting Information (Figures S11 and S12). The ITC data have been analysed using one-site binding model for the binary systems $\left[\operatorname{Re}_{6} \mathrm{Q}_{8}(\mathrm{CN})_{6}\right]^{4-} / \mathrm{CD}$.

Firstly, ITC data show that the binding of rhenium clusters with $\alpha-$ or $\beta-C D$ is an enthalpically driven process accompanied with an entropic penalty. This thermodynamic signature could correspond to the typical binding of chaotropic entities to CDs. . $^{7,10,12}$ Therefore, the main driving force of the supramolecular complexation would be the bulk water structure recovery from the solvation shell of the chaotropic clusters. Furthermore, increasing of enthalpic contribution along $\left[\operatorname{Re}_{6} \mathrm{Q}_{8}(\mathrm{CN})_{6}\right]^{4-/ C D}$ series is balanced by an increasing entropy penalty according to enthalpy-entropy compensation usually observed as a quasi-linear correlation (Figure 7a). 
Table 1. Binding constants $K$ involving rhenium octahedral clusters with native $\mathrm{CDs}(\alpha-, \beta-$ and $\gamma-\mathrm{CD})$ and associated thermodynamic parameters (in $\mathrm{kJ} . \mathrm{mol}^{-1}$ ) at $\mathrm{T}=298 \mathrm{~K}$

\begin{tabular}{|c|c|c|c|c|c|c|c|}
\hline $\mathrm{CD}$ & $\mathrm{Q}$ & $\mathrm{Step}$ & $K\left(\mathrm{M}^{-1}\right)$ & $\Delta_{\mathrm{r}} H^{*}$ & $T \Delta_{\mathrm{r}} S^{*}$ & $\Delta_{\mathrm{r}} G^{*}$ & Refs \\
\hline \multirow{4}{*}{$\alpha-\mathrm{CD}$} & $\mathrm{S}$ & $1: 1$ & $727^{\mathrm{a}} / 270^{\mathrm{b}}$ & -40.6 & -24.3 & -16.3 & This work \\
\cline { 2 - 8 } & $\mathrm{Se}$ & $1: 1$ & $-^{\mathrm{c}} / 30^{\mathrm{b}}$ & $-^{\mathrm{d}}$ & $-^{\mathrm{d}}$ & $-^{\mathrm{d}}$ & This work \\
\cline { 2 - 8 } & $\mathrm{Te}$ & $1: 1$ & $-^{\mathrm{c}} /-^{\mathrm{c}}$ & $-^{\mathrm{d}}$ & $-^{\mathrm{d}}$ & $-^{\mathrm{d}}$ & This work \\
\hline \multirow{4}{*}{$\beta-\mathrm{CD}$} & $\mathrm{S}$ & $1: 1$ & $884^{\mathrm{a}} / 640^{\mathrm{b}}$ & -40.6 & -23.8 & -16.8 & This work \\
\cline { 2 - 8 } & $\mathrm{Se}$ & $1: 1$ & $749^{\mathrm{a}} / 780^{\mathrm{b}}$ & -27.4 & -11.0 & -16.4 & This work \\
\cline { 2 - 8 } & $\mathrm{Te}$ & $1: 1$ & $-^{\mathrm{c}} / 84^{\mathrm{b}}$ & $-^{\mathrm{d}}$ & $-^{\mathrm{d}}$ & $-^{\mathrm{d}}$ & This work \\
\hline \multirow{5}{*}{$\gamma-\mathrm{CD}$} & $\mathrm{S}$ & $1: 1$ & $900^{\mathrm{a}}$ & -63.2 & -46.4 & -16.8 & 9 \\
\cline { 2 - 8 } & \multirow{2}{*}{$\mathrm{Se}$} & $1: 1$ & $1500^{\mathrm{a}}$ & -30.4 & -12.3 & -18.1 & 9 \\
\cline { 2 - 8 } & \multirow{2}{*}{$\mathrm{Te}$} & $1: 2$ & $300^{\mathrm{a}}$ & -56.5 & -42.7 & -13.8 & \\
& & $1: 1$ & $37700^{\mathrm{a}}$ & -25.3 & +0.8 & -26.1 & \multirow{2}{*}{} \\
& & $12700^{\mathrm{a}}$ & -51.0 & -27.7 & -23.4 & \\
\hline
\end{tabular}

a determined by ITC, ${ }^{b}$ determined by ${ }^{1} \mathrm{H}$ NMR titration, $\mathrm{c}$ binding constant is too weak to be determined, d no significant heat release detected..

Secondly, we observe that binding constants $K$ obtained with $\alpha-$ and $\beta-C D$ are smaller than values observed for $\gamma-C D$. This is understood by considering i) the desolvation process of the guest by the macrocycle host and ii) the size/shape compatibility between both components of the inclusion complex. As observed in X-ray crystal structures (Figure 5), the small CDs $(\alpha-$ and $\beta-C D)$ encapsulate partially the inorganic guest, unlike $\gamma-\mathrm{CD}$ gives deep embedment. In short, a deep inclusion process is expected to release a large number of 'disordered' water molecules, resulting in a larger entropic penalty (see Table 1 and Table S3). Actually, this desolvation effect is then directly dependent of the host-guest shape complementarity but also dependent on their respective size and on the extent of their interacting interface. The binding constants for the larger cluster, $\left[\mathrm{Re}_{6} \mathrm{Te}_{8}(\mathrm{CN})_{6}\right]^{4-}$ vary strongly in $\alpha-, \beta-C D$ and $\gamma-C D$ series. In fact, this cluster is too large to enter into the $\alpha-$ and $\beta-\mathrm{CD}$ but fits perfectly with $\gamma-\mathrm{CD}$ cavity size, resulting in the larger $K_{11}$ stability constant $\left(\mathrm{K}_{11}=37\right.$ 700).

A concomitant effect associated to the decreasing size of the cluster (from Te to S) weakens the host-guest supramolecular cohesion observed in the solid state with the significant increase of the shortest host-guest separations. Then a hostguest fitting geometrical parameter (noted $R$ ) can be introduced as the ratio between the average outer diameter of one face of the octahedral $\left\{\operatorname{Re}_{6} \mathrm{Q}_{8}\right\}$ core and the average inner diameter of the CD (see Figure 7b). Depending on the hostguest system, $R$ parameter values spread from 0.82 to 1.5 enclosing $R=1$, a value which is expected for the best hostguest matching. Actually, the tellurium-containing cluster $/ \gamma$ CD system is featured by the $R$ value closest to $1(R=0.97)$ values while this supramolecular system exhibits the highest $K_{11}$ value (see Figure $7 \mathrm{c}$ ). It is worth mentioning that deviation of $R$ value from 1 on both sides leads to host-guest systems exhibiting very low or moderate $K_{11}$ values below 1000 $\mathrm{M}^{-1}$.

Furthermore, geometrical disagreement should be enhanced by host-guest symmetry mismatching, for instance $O_{\mathrm{h}}$ for the cluster and $\mathrm{C}_{7}$ for $\beta-\mathrm{CD}$. These results demonstrate that a size-exclusion mechanism prevails within the host-guest a)
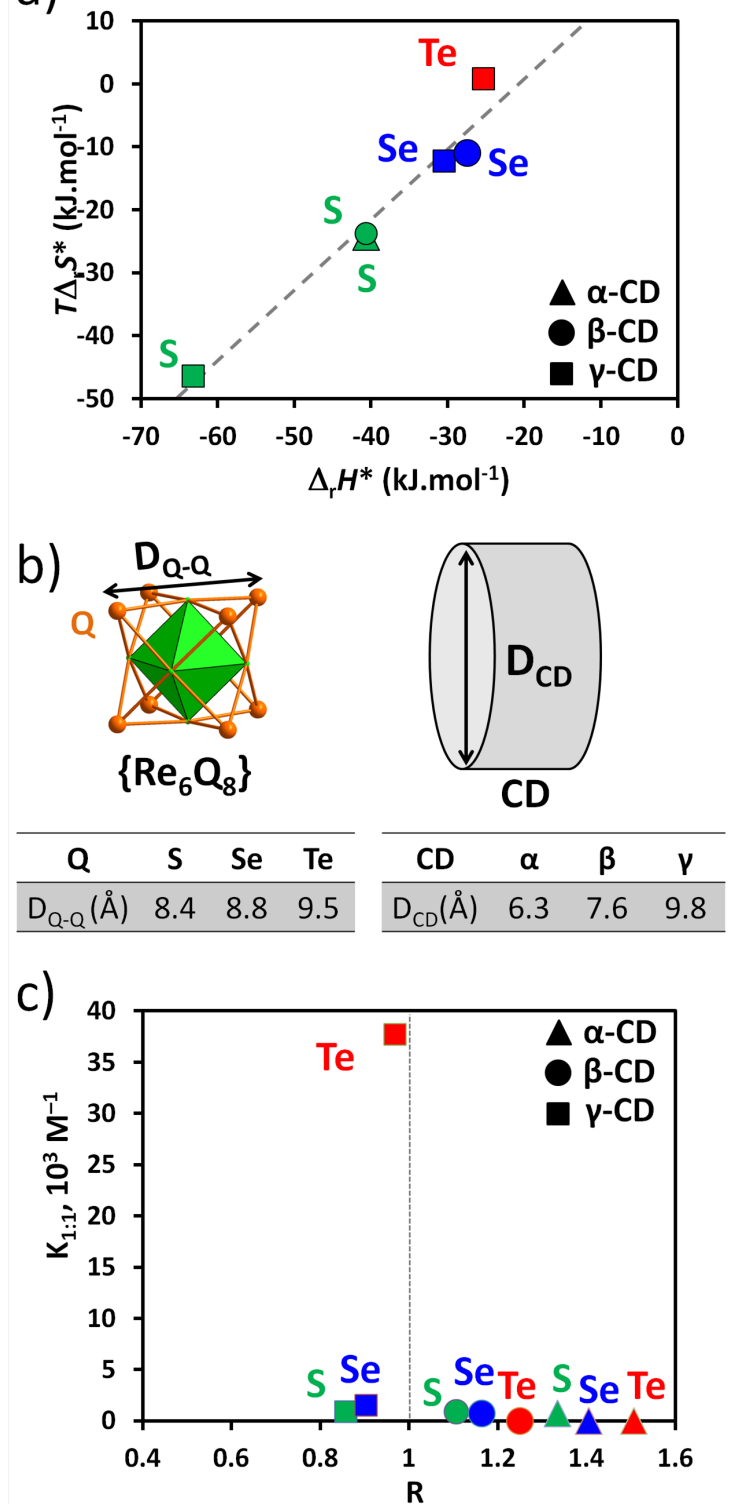

Figure 7. a) Enthalpy-entropy compensation plot for 1:1 cyclodextrin complexes with $\left[\operatorname{Re}_{6} \mathrm{Q}_{8}(\mathrm{CN})_{6}\right]^{4-}$. b) Schematic representation showing the structural parameters used for the calculation of the host-guest structural fitting parameter $\mathrm{R}$ determined from the following equation: $\mathrm{R}=\mathrm{D}_{\mathrm{Q}}$ $\mathrm{Q} / \mathrm{D}_{\mathrm{CD}}$. c) Evolution of the one-site binding constant as a function of hostguest fitting parameter $R$.

recognition process favoured by both the solvent effects and optimization of attractive dispersion forces. Besides, full analysis of the thermodynamic data reveals that all the $\left[\mathrm{Re}_{6} \mathrm{Q}_{8}(\mathrm{CN})_{6}\right]^{4-}$ clusters exhibit a chaotropic behaviour, identified as one possible main contributors within aggregation processes in aqueous solution. ${ }^{13}$ It should even worth mentioning that some of these species, such as the Keggin polyoxotungstate $\left[\mathrm{PW}_{12} \mathrm{O}_{40}\right]^{3-}$ or halide dodecaborate ions $\left[\mathrm{B}_{12} \mathrm{X}_{12}\right]^{2-}$ (with $\mathrm{X}=\mathrm{Cl}, \mathrm{Br}$ or $\mathrm{I}$ ) have been referred as "superchaotrope" within the extended Hofmeister scale. Furthermore, in the halide dodecaborate series $\left[\mathrm{B}_{12} \mathrm{X}_{12}\right]^{2-}$ the chaotropic character has been correlated to the halide polarizability, increasing the chaotropic nature when $\mathrm{X}$ varies from $\mathrm{Cl}$ to I. ${ }^{10}$ Surprisingly, as shown in Figure $7 \mathrm{a}$ for the 

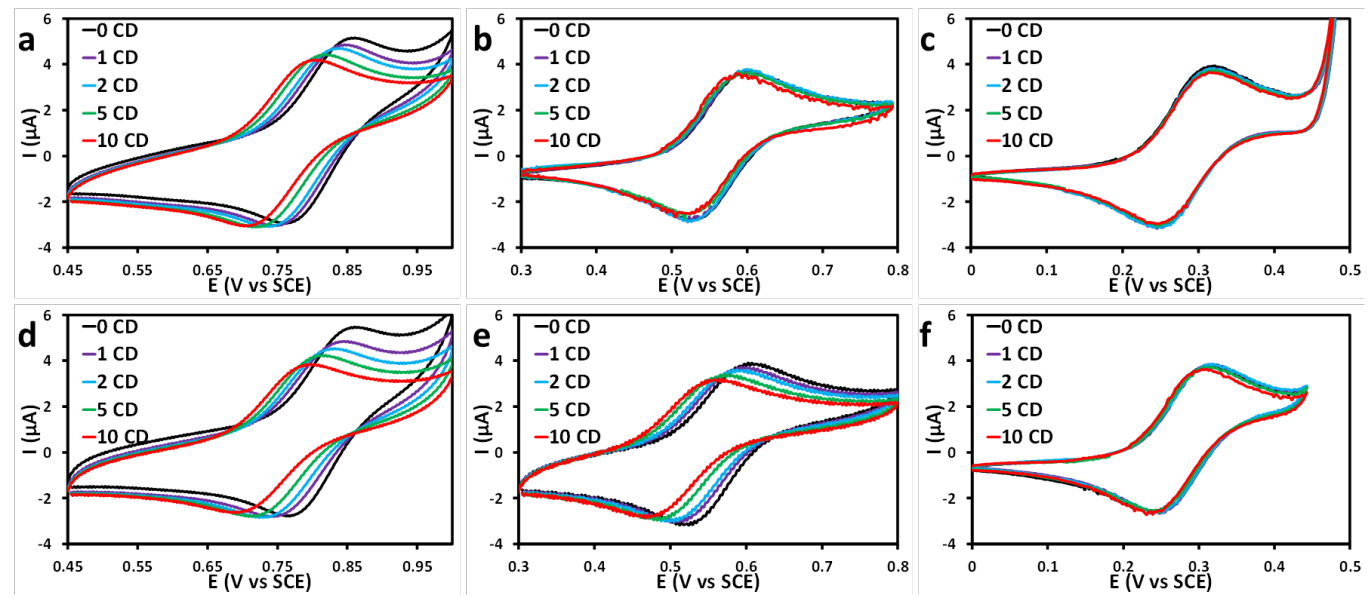

Figure 8: Cyclic voltammetry of the $\left[\operatorname{Re}_{6} \mathrm{Q}_{8}(\mathrm{CN})_{6}\right]^{4-}$ anions $\left(0.5 \mathrm{mmol} \cdot \mathrm{L}^{-1}, 2.5 \mathrm{mmol} . \mathrm{L}^{-1} \mathrm{HClO}_{4}\right.$ aqueous solution, glassy carbon working electrode, scan rate $\left.50 \mathrm{mV} \cdot \mathrm{s}^{-1}\right)$ in the presence of increasing amounts of $\alpha-\mathrm{CD}(\mathrm{Q}=\mathrm{S}(\mathrm{a})$, Se (b) or Te (c)) or $\beta-\mathrm{CD}(\mathrm{Q}=\mathrm{S}(\mathrm{d})$, Se (e) or Te (f))..

$\left[\operatorname{Re}_{6} \mathrm{Q}_{8}(\mathrm{CN})_{6}\right]^{4-}$ series, the magnitude of the chaotropic character varies as the inverse of the polarizability of the chalcogenide $\mathrm{Q}$ in the order $\mathrm{S}>\mathrm{Se}>\mathrm{Te}$, while an opposite trend could be expected. ${ }^{9}$ Such an observation can be understood from antagonist influence arising from the six exposed cyano groups. Actually, as the $\sigma$ donor capability of the $\mathrm{Q}$ ligands toward the $\mathrm{Re}$ centers increases from $\mathrm{S}$ to $\mathrm{Te}$, the $\mathrm{Re}-\mathrm{C}$ $\sigma$ overlap weakens with direct consequence of increase of the cyano group polarization. ${ }^{41}$ Then, as the charge density decreases on the Q ligands from $\mathrm{S}$ to $\mathrm{Te}$, ionic charge density at the six exposed cyano ligands increases concomitantly to cancel partially the expected chaotropic nature of the cluster.

Electrochemistry. The cyclic voltammograms of rhenium clusters show a reversible monoelectronic wave leading to the oxidized entities $\left[\operatorname{Re}_{6} \mathrm{Q}_{8}(\mathrm{CN})_{6}\right]^{3-}$. In our previous study, we observed the encapsulation of rhenium clusters within $\gamma-\mathrm{CD}$ affects strongly the electrochemical signature of guest. ${ }^{9}$ Such effect is commonly observed when the reduced and the oxidized states exhibit a different affinity with a macrocyclic host. ${ }^{5,9,42-44}$ Herein we investigate the effect of $\alpha-$ and $\beta-C D$ on the redox properties of $\left[\operatorname{Re}_{6} \mathrm{Q}_{8}(\mathrm{CN})_{6}\right]^{4-}$. Figure 8 shows the cyclic voltammograms of rhenium clusters $\left[\mathrm{Re}_{6} \mathrm{Q}_{8}(\mathrm{CN})_{6}\right]^{4-}$ in presence of various amounts of cyclodextrins (from 0 to 10 equivalents of CDs) in $2.5 \mathrm{mM}$ perchloric acid aqueous solution. Almost no modification of cyclic voltammograms is observed in the experiments involving the $\left[\mathrm{Re}_{6} \mathrm{Se}_{8}(\mathrm{CN})_{6}\right]^{4-}$ and $\left[\mathrm{Re}_{6} \mathrm{Te}_{8}(\mathrm{CN})_{6}\right]^{4-}$ with $\alpha-\mathrm{CD}$ as well as for $\left[\operatorname{Re}_{6} \mathrm{Te}_{8}(\mathrm{CN})_{6}\right]^{4-}$ with $\beta-\mathrm{CD}$. These results confirm the lack of any significant host-guest interactions with the reduced species and indicate that no more interaction holds with the oxidized species. Conversely, the interaction of sulphur-based cluster with $\alpha-\mathrm{CD}$ or $\beta-\mathrm{CD}$ is featured by a gradual decreasing of the half-wave potential $\mathrm{E}^{1 / 2} \mathrm{2}^{\mathrm{app}}$ which is also associated to a weak decrease of the peak currents. Similarly the selenium based cluster exhibits the same behaviour with $\beta-C D$. The variation of the half-wave potential indicates that cyclodextrin is involved within the one electron transfer process, consistent with an increase of the host-guest affinity through the cluster oxidation. Further- more, the substantial reduction of the peak currents due to the decrease of the diffusion coefficient is the fingerprint of a supramolecular process induced by the oxidation reaction.

In the electrochemical conditions $(0.5 \mathrm{mM}$ cluster solution and up to 10 eq. of $\mathrm{CD}$ ), the speciation diagram established from the stability constants shows that the 1:1 inclusion complex is the predominant reduced species. Then the corresponding redox reaction should be expressed as Equation 1 and the related Nernst equation given in Equation 2 could be considered. ${ }^{9}$

$$
\begin{gathered}
{\left[\operatorname{Re}_{6} \mathrm{Q}_{8}(\mathrm{CN})_{6} @ \mathrm{CD}\right]^{4-}+\mathrm{CD}=\left[\mathrm{Re}_{6} \mathrm{Q}_{8}(\mathrm{CN})_{6} @ 2 \mathrm{CD}\right]^{3-}+1 \mathrm{e}^{-}(1)} \\
\mathrm{E}_{1 / 2}^{\mathrm{app}}=\mathrm{E}_{1 / 2}^{\mathrm{CD}}+0.059 p \mathrm{CD}
\end{gathered}
$$

where $p \mathrm{CD}=-\log [\mathrm{CD}]$ and $\mathrm{E}_{1 / 2}^{\mathrm{CD}}$ is the half-wave potential of the redox couple $\quad\left[\mathrm{Re}_{6} \mathrm{Q}_{8}(\mathrm{CN})_{6} @ 2 \mathrm{CD}\right]^{3-}$ $/\left[\operatorname{Re}_{6} \mathrm{Q}_{8}(\mathrm{CN})_{6} @ \mathrm{CD}\right]^{4-}, \mathrm{CD}$. However, it must be worth mentioning that $\mathrm{ClO}_{4}^{-}$ions from electrolyte compete with the cluster complexation since perchlorate anions are known to interact weakly with $\alpha-\mathrm{CD}(K=16-66 \text { mol.L-1 })^{45-48}$ and $\beta-\mathrm{CD}(K=9-16$ mol.L-1 $) .{ }^{48,49}$ Herein, this competitive effect becomes negligible as concentration of perchloric acid remains below $2.5 \mathrm{mM} \mathrm{HClO}_{4}$. In such conditions, the halfwave potentials $\mathrm{E}_{1 / 2}^{\mathrm{CD}}$ vary linearly as a function of $p C D$ with slopes close to the expected value of about $59 \mathrm{mV}$ per $p C D$ unit (Figure S13). For higher concentration in perchloric acid (up to $25 \mathrm{mM}$ ), competition processes between clusters and $\mathrm{ClO}_{4}^{-}$anions change significantly the clusters speciation which reduces the half-wave potential dependency upon the $p C D$ (Figure S14-S16).

Table 2. Calculated global formation constant related to Equation 3.

\begin{tabular}{|c|c|c|c|}
\hline $\mathrm{Q}$ & $\mathrm{CD}$ & $\beta_{2}^{\prime}\left(\mathrm{M}^{-2}\right)$ & Refs \\
\hline \multirow{3}{*}{$\mathrm{S}$} & $\alpha-\mathrm{CD}$ & $2.310^{6}$ & This work \\
\cline { 2 - 4 } & $\beta-\mathrm{CD}$ & $310^{6}$ & This work \\
\cline { 2 - 4 } & $\gamma-\mathrm{CD}$ & $2.210^{7}$ & 9 \\
\hline \multirow{2}{*}{$\mathrm{Se}$} & $\beta-\mathrm{CD}$ & $1.610^{6}$ & This work \\
\hline
\end{tabular}


The half-wave potential $E_{1 / 2}^{C D}$ of each redox couple $\left[\operatorname{Re}_{6} \mathrm{Q}_{8}(\mathrm{CN})_{6} @ 2 \mathrm{CD}\right]^{3-} /\left[\mathrm{Re}_{6} \mathrm{Q}_{8}(\mathrm{CN})_{6} @ \mathrm{CD}\right]^{4-}, \mathrm{CD}$ has been determined from the Equation 1 (Table S4). The global formation constants $\beta_{2}^{\prime}$ related to Equation 3 have been determined (Table 2) using the Equation 4 where $K_{1: 1}$ corresponds to the stability constant of the reduced forms determined by ITC, $E_{1 / 2}^{0}$ is the standard potential of the redox couple $\left[\operatorname{Re}_{6} \mathrm{Q}_{8}(\mathrm{CN})_{6}\right]^{3-} /\left[\operatorname{Re}_{6} \mathrm{Q}_{8}(\mathrm{CN})_{6}\right]^{4-}$ and $\mathrm{E}_{1 / 2}^{\mathrm{CD}}$ is the redox potential associated to the redox couple involved in Equation 1.

$$
\begin{aligned}
& {\left[\operatorname{Re}_{6} \mathrm{Q}_{8}(\mathrm{CN})_{6}\right]^{3-}+2 \mathrm{CD}=\left[\operatorname{Re}_{6} \mathrm{Q}_{8}(\mathrm{CN})_{6} @ 2 \mathrm{CD}\right]^{3-}} \\
& \mathrm{E}_{1 / 2}^{0}=\mathrm{E}_{1 / 2}^{\mathrm{CD}}+0.059 \log \frac{\beta_{2}^{\prime}}{\mathrm{K}_{1: 1}}
\end{aligned}
$$

This result highlights the high affinity of the oxidized species for CDs able to produce the 2:1 complexes. The calculated binding constants $\beta_{2}^{\prime}$ for sulphur cluster with CDs lie in the same order of magnitude, showing the weak selectivity as observed for its reduced homologues, and then rather consistent with a predominant solvent effect.

ESI-MS. ESI-MS is useful for investigating supramolecular recognition competition reactions. ${ }^{50,51}$ For each rhenium cluster, competitive host-guest complexation in ESI-MS has been carried out on aqueous mixtures containing two equivalents of each native $\mathrm{CD}(\alpha-, \beta-$, and $\gamma-\mathrm{CD})$. Although the ionization process involves oxidation of the cluster complexes $\left[\mathrm{Re}_{6} \mathrm{Q}_{8}(\mathrm{CN})_{6}\right]^{4-}$ into $\left[\mathrm{Re}_{6} \mathrm{Q}_{8}(\mathrm{CN})_{6}\right]^{3-}$, ESI-MS study nicely corroborates the conclusions arising from solution investigations on the reduced derivatives. This study indicates that sulphur based cluster forms supramolecular adducts with all cyclodextrins, unlike the selenium and the tellurium derivatives which are mainly bound to larger CDs. All ESI-MS spectra and their detailed interpretation are provided in Supporting Information (see, Figures S17-S19 and Tables S5S7). Briefly, it was found that sulphur derivative forms 1:1 adducts with each cyclodextrin $\left(\left\{\left[\operatorname{Re}_{6} \mathrm{~S}_{8}(\mathrm{CN})_{6}\right](\alpha-\mathrm{CD})\right\}^{3-}\right.$ $(\mathrm{m} / \mathrm{z}=833.93),\left\{\left[\operatorname{Re}_{6} \mathrm{~S}_{8}(\mathrm{CN})_{6}\right](\beta-\mathrm{CD})\right\}^{3-}(\mathrm{m} / \mathrm{z}=887.94)$ and $\left.\left\{\left[\operatorname{Re}_{6} \mathrm{~S}_{8}(\mathrm{CN})_{6}\right](\gamma-\mathrm{CD})\right\}^{3-}(\mathrm{m} / \mathrm{z}=941.97)\right)$. In case of Secontaining cluster complexation forms only with $\beta-$ and $\gamma-\mathrm{CD} \quad\left(\left\{\left[\mathrm{Re}_{6} \mathrm{Se}_{8}(\mathrm{CN})_{6}\right](\beta-\mathrm{CD})\right\}^{3-}(\mathrm{m} / \mathrm{z}=1013.78)\right.$ and $\left.\left\{\left[\operatorname{Re}_{6} \mathrm{Se}_{8}(\mathrm{CN})_{6}\right](\gamma-\mathrm{CD})\right\}^{3-}(\mathrm{m} / \mathrm{z}=1067.79)\right)$ with two times more intense mass-peaks for $\gamma-\mathrm{CD}$. The tellurium containing cluster forms complex only with $\gamma-\mathrm{CD}$ $\left(\left\{\left[\operatorname{Re}_{6} \mathrm{Te}_{8}(\mathrm{CN})_{6}\right](\gamma-\mathrm{CD})\right\}^{3-}(\mathrm{m} / \mathrm{z}=1197.10)\right)$.

Circular dichroism. Induced circular dichroism is generally observed when achiral guest interacts specifically with chiral host such as cyclodextrins, ${ }^{52,53}$ silica nanohelices ${ }^{54}$ or proteins. ${ }^{55}$ Circular dichroism investigations have been carried out on aqueous solutions containing $\left[\operatorname{Re}_{6} \mathrm{Q}_{8}(\mathrm{CN})_{6}\right]^{4-}$ and large excess of CDs. The circular dichroism spectrum of $\left[\mathrm{Re}_{6} \mathrm{Te}_{8}(\mathrm{CN})_{6}\right]^{4-}$ in presence of $\gamma-\mathrm{CD}$ shows a strong negative Cotton signal at $212 \mathrm{~nm}$, a strong positive signal located at $228 \mathrm{~nm}$, and two weak and broad negative signals at around 248 and $300 \mathrm{~nm}$ (Figure 9). In contrast, this cluster exhibits no signal in presence of $\alpha-$ and $\beta-C D$ (Figure 9). The cluster $\left[\operatorname{Re}_{6} \mathrm{Se}_{8}(\mathrm{CN})_{6}\right]^{4-}$ shows similar features than
$\left[\mathrm{Re}_{6} \mathrm{Te}_{8}(\mathrm{CN})_{6}\right]^{4-}$. In fact, Se- derivative exhibits no chilarity induction in presence of small CDs, while two strong Cotton peaks located at $215 \mathrm{~nm}$ (negative signal) and $237 \mathrm{~nm}$ (positive signal) are detected for aqueous mixture of Se based cluster and $\gamma-\mathrm{CD}$ (Figure S20). A different situation occurs on sulphur based cluster in presence of $\gamma-\mathrm{CD}$, which is probably due to its distinct supramolecular behaviour, since only weak positive Cotton signals are observed at 224 and $281 \mathrm{~nm}$ (Figure S20). As for Se and Te derivatives, no chirality induction takes place with $\left[\operatorname{Re}_{6} \mathrm{~S}_{8}(\mathrm{CN})_{6}\right]^{4-}$ in presence of $\alpha-$ and $\beta-\mathrm{CD}$. The circular dichroism investigation reveals that the chirality induction from cyclodextrin to the cluster is clearly correlated with the specificity of the host-guest interactions in solution. Actually, as usually observed, the transfer of chirality arises from deep host-guest inclusion and therefore it occurs exclusively in presence of largest cyclodextrin $(\gamma-\mathrm{CD})$.

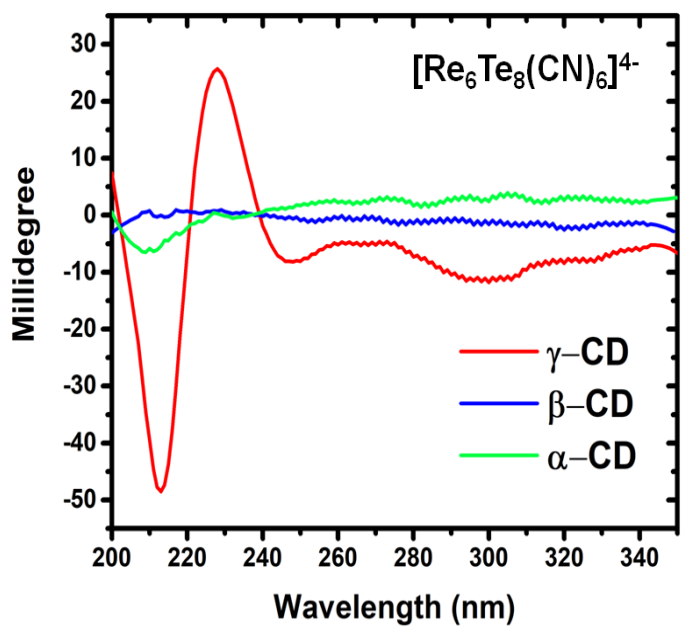

Figure 9: Comparison of the circular dichroism spectra of tellurium derivative in presence of cyclodextrins. Such results underline that deep inclusion of the cluster inside $\gamma-\mathrm{CD}$ provokes a remarkable chirality induction.

\section{Conclusions}

Herein, we reported on the systematic investigation of the cyclodextrin size cavity effect $(\alpha-, \beta-$ and $\gamma-C D)$ toward the supramolecular complexation of octahedral rhenium clusters $\left[\operatorname{Re}_{6} \mathrm{Q}_{8}(\mathrm{CN})_{6}\right]^{4-}(\mathrm{Q}=\mathrm{S}$, Se, and Te). Single-crystal X-ray diffraction analysis allowed determining structural arrangements for all CD-cluster combinations showing either cocrystallized hybrid systems or host-guest supramolecular complexes. In addition, aqueous solution behaviour has been studied carefully through a set of complementary techniques (NMR, ESI-MS, ITC, electrochemistry and circular dichroism). These results underline that $\left[\operatorname{Re}_{6} \mathrm{Q}_{8}(\mathrm{CN})_{6}\right]^{4-}$ exhibits contrasting behaviour upon the host-guest binding, allowing a selective molecular recognition of the clusters by the appropriate cyclodextrin. The sulphur derivative which is the strongest water-structure breaker in the cluster series interacts with all CDs forming 1:1 host-guest complex having comparable stability constant in solution, indicating the selfassembly process is mainly driven by desolvation process of 
the clusters. On the other hand, the intermediary-sized cluster $\left[\mathrm{Re}_{6} \mathrm{Se}_{8}(\mathrm{CN})_{6}\right]^{4-}$ interacts with both $\beta$ - and $\gamma-\mathrm{CD}$ while the larger $\left[\operatorname{Re}_{6} \mathrm{Te}_{8}(\mathrm{CN})_{6}\right]^{4-}$ interacts exclusively with the $\gamma-\mathrm{CD}$ giving strongest inclusion complex featured by two orders of magnitude higher stability constant. Such results evidence that selectivity of the aggregation processes arises from a size-exclusion mechanism that requires at least partial hostguest inclusion to generate stable assembly.

\section{ASSOCIATED CONTENT}

\section{Supporting Information}

The Supporting Information is available free of charge on the ACS Publications website.

Crystal data, FT-IR spectra of $\operatorname{Re}_{6} \mathbf{S}_{8} @ \alpha-C D, \operatorname{Re}_{6} \mathbf{S e}_{8}(\alpha-C D)$, $\operatorname{Re}_{6} T_{8}(\alpha-C D), R_{6} S_{8} @ \beta-C D, R_{6} S_{8} @ \beta-C D$ and $R_{6} T_{1} @ \beta-C D$. ${ }^{1} \mathrm{H},{ }^{77} \mathrm{Se}$ and ${ }^{125} \mathrm{Te}$ NMR spectra resulting from the titration of CDs by clusters. ITC measurements including termograms. Electrochemical and ESI-MS investigations and circular dichroism spectra.

Accession Codes : CCDC 1905524-1905529 contain the supplementary crystal-lographic data for this paper. These data can be obtained free of charge viawww.ccdc.cam.ac.uk/data_request/cif.

\section{AUTHOR INFORMATION}

\section{Corresponding Author}

* E-mail : clement.falaise@uvsq.fr

\section{Notes}

The authors declare no competing financial interest.

\section{ACKNOWLEDGMENT}

The authors acknowledge A. Damond for her technical help in ESI-MS measurements. Authors gratefully acknowledge financial support from LIA-CNRS CLUSPOM, CNRS MOMENTUM and LabEx CHARMMMAT (ANR-11LBX-0039-grant). This work was also supported by i) University of Versailles Saint Quentin, ii) CNRS, iii) Région Ile de France through DIM Nano K, iv) Russian Science Foundation (No. 15-15-10006). NIIC thanks the Ministry of Science and Education of the Russian Federation. A.A. Ivanov thanks Embassy of France in Russia for the Vernadsky scholarship for post-graduate students.

\section{REFERENCES}

(1) Connors, K. A. The Stability of Cyclodextrin Complexes in Solution. Chem. Rev. 1997, 97 (5), 1325-1358. https://oi.org/10.1021/cr960371r.

(2) Davis, M. E.; Brewster, M. E. Cyclodextrin-Based Pharmaceutics: Past, Present and Future. Nat. Rev. Drug Discov. 2004, 3 (12), 1023-1035. https://doi.org/10.1038/nrd1576.

(3) Del Valle, E. M. M. Cyclodextrins and Their Uses: A Review. Process Biochem. 2004, 39 (9), 1033-1046. https://doi.org/10.1016/S0032-9592(03)00258-9.

(4) Crini, G. Review: A History of Cyclodextrins. Chem. Rev. 2014, 114 (21), 10940-10975. https://doi.org/10.1021/cr500081p.
(5) Wu, Y.; Shi, R.; Wu, Y.-L.; Holcroft, J. M.; Liu, Z.; Frasconi, M.; Wasielewski, M. R.; Li, H.; Stoddart, J. F. Complexation of Polyoxometalates with Cyclodextrins. J. Am. Chem. Soc. 2015, 137 (12), 4111-4118. https://doi.org/10.1021/ja511713c.

(6) Moussawi, M. A.; Haouas, M.; Floquet, S.; Shepard, W. E.; Abramov, P. A.; Sokolov, M. N.; Fedin, V. P.; Cordier, S.; Ponchel, A.; Monflier, E.; et al. Nonconventional ThreeComponent Hierarchical Host-Guest Assembly Based on Mo-Blue Ring-Shaped Giant Anion, $\gamma$-Cyclodextrin, and Dawson-Type Polyoxometalate. J. Am. Chem. Soc. 2017, 139 (41), 14376-14379. https://doi.org/10.1021/jacs.7b08058.

Moussawi, M. A.; Leclerc-Laronze, N.; Floquet, S.; Abramov, P. A.; Sokolov, M. N.; Cordier, S.; Ponchel, A.; Monflier, E.; Bricout, H.; Landy, D.; et al. Polyoxometalate, Cationic Cluster, and $\gamma$-Cyclodextrin: From Primary Interactions to Supramolecular Hybrid Materials. J. Am. Chem. Soc. 2017, $\quad 139 \quad$ (36), 12793-12803. https://doi.org/10.1021/jacs.7b07317.

(8) Falaise, C.; Moussawi, M. A.; Floquet, S.; Abramov, P. A.; Sokolov, M. N.; Haouas, M.; Cadot, E. Probing Dynamic Library of Metal-Oxo Building Blocks with $\gamma$-Cyclodextrin. J. Am. Chem. Soc. 2018, 140 (36), 11198-11201. https://doi.org/10.1021/jacs.8b07525.

Ivanov, A. A.; Falaise, C.; Abramov, P. A.; Shestopalov, M. A.; Kirakci, K.; Lang, K.; Moussawi, M. A.; Sokolov, M. N.; Naumov, N. G.; Floquet, S.; et al. Host-Guest Binding Hierarchy within Redox- and Luminescence-Responsive Supramolecular Self-Assembly Based on Chalcogenide Clusters and $\gamma$-Cyclodextrin. Chem. - Eur. J. 2018, 24 (51), $13467-$ 13478. https://doi.org/10.1002/chem.201802102.

(10) Assaf, K. I.; Ural, M. S.; Pan, F.; Georgiev, T.; Simova, S.; Rissanen, K.; Gabel, D.; Nau, W. M. Water Structure Recovery in Chaotropic Anion Recognition: High-Affinity Binding of Dodecaborate Clusters to $\gamma$-Cyclodextrin. Angew. Chem. Int. Ed. 2015, 54 (23), 6852-6856. https://doi.org/10.1002/anie.201412485.

(11) Assaf, K. I.; Suckova, O.; Al Danaf, N.; von Glasenapp, V.; Gabel, D.; Nau, W. M. Dodecaborate-Functionalized Anchor Dyes for Cyclodextrin-Based Indicator Displacement Applications. Org. Lett. 2016, 18 (5), 932-935. https://doi.org/10.1021/acs.orglett.5b03611.

(12) I. Assaf, K.; Gabel, D.; Zimmermann, W.; M. Nau, W. HighAffinity Host-Guest Chemistry of Large-Ring Cyclodextrins. Org. Biomol. Chem. 2016, 14 (32), 7702-7706. https://doi.org/10.1039/C6OB01161F.

(13) Assaf, K. I.; Nau, W. M. The Chaotropic Effect as an Assembly Motif in Chemistry. Angew. Chem. Int. Ed. 2018, 57 (43), 13968-13981. https://doi.org/10.1002/anie.201804597.

(14) Buchecker, T.; Schmid, P.; Renaudineau, S.; Diat, O.; Proust, A.; Pfitzner, A.; Bauduin, P. Polyoxometalates in the Hofmeister Series. Chem. Commun. 2018, 54 (15), 18331836. https://doi.org/10.1039/C7CC09113C.

(15) Wang, W.; Wang, X.; Cao, J.; Liu, J.; Qi, B.; Zhou, X.; Zhang, S.; Gabel, D.; Nau, W. M.; Assaf, K. I.; et al. The Chaotropic Effect as an Orthogonal Assembly Motif for Multi-Responsive Dodecaborate-Cucurbituril Supramolecular Networks. Chem. Commun. 2018, 54 (17), 2098-2101. https://doi.org/10.1039/C7CC08078F.

(16) Naskar, B.; Diat, O.; Nardello-Rataj, V.; Bauduin, P. Nanometer-Size Polyoxometalate Anions Adsorb Strongly on Neutral Soft Surfaces. J. Phys. Chem. C 2015, 119 (36), 20985-20992. https://doi.org/10.1021/acs.jpcc.5b06273.

(17) Warneke, J.; Jenne, C.; Bernarding, J.; Azov, V. A.; Plaumann, M. Evidence for an Intrinsic Binding Force between Dodecaborate Dianions and Receptors with Hydrophobic Binding Pockets. Chem. Commun. 2016, 52 (37), 6300 6303. https://doi.org/10.1039/C6CC01233G.

Assaf, K. I.; Hennig, A.; Peng, S.; Guo, D.-S.; Gabel, D.; Nau, W. M. Hierarchical Host-Guest Assemblies Formed on 
Dodecaborate-Coated Gold Nanoparticles. Chem. Commun. 2017, $\quad 53 \quad$ (33), $\quad 4616-4619$ https://doi.org/10.1039/C7CC01507K.

(19) Kobayashi, D.; Nakahara, H.; Shibata, O.; Unoura, K.; Nabika, H. Interplay of Hydrophobic and Electrostatic Interactions between Polyoxometalates and Lipid Molecules. $J$. Phys. Chem. C 2017, 121 (23), 12895-12902. https://doi.org/10.1021/acs.jpcc.7b01774.

(20) Jing, B.; Hutin, M.; Connor, E.; Cronin, L.; Zhu, Y. Polyoxometalate Macroion Induced Phase and Morphology Instability of Lipid Membrane. Chem. Sci. 2013, 4 (10), 38183826. https://doi.org/10.1039/C3SC51404H.

(21) Geng, J.; Li, M.; Ren, J.; Wang, E.; Qu, X. Polyoxometalates as Inhibitors of the Aggregation of Amyloid $\beta$ Peptides Associated with Alzheimer's Disease. Angew. Chem. Int. Ed. 2011, $50 \quad$ (18), 4184-4188 https://doi.org/10.1002/anie.201007067.

(22) Bijelic, A.; Rompel, A. Polyoxometalates: More than a Phasing Tool in Protein Crystallography. ChemTexts 2018, 4 (3), 10. https://doi.org/10.1007/s40828-018-0064-1.

(23) Vandebroek, L.; De Zitter, E.; Ly, H. G. T.; Conić, D.; Mihaylov, T.; Sap, A.; Proost, P.; Pierloot, K.; Van Meervelt, L.; Parac-Vogt, T. N. Protein-Assisted Formation and Stabilization of Catalytically Active Polyoxometalate Species. Chem. - Eur. J. 2018, 24 (40), 10099-10108. https://doi.org/10.1002/chem.201802052.

(24) Goszczyński, T. M.; Fink, K.; Kowalski, K.; Leśnikowski, Z. J.; Boratyński, J. Interactions of Boron Clusters and Their Derivatives with Serum Albumin. Sci. Rep. 2017, 7 (1), 9800. https://doi.org/10.1038/s41598-017-10314-0.

(25) Molard, Y.; Dorson, F.; Cîrcu, V.; Roisnel, T.; Artzner, F.; Cordier, S. Clustomesogens: Liquid Crystal Materials Containing Transition-Metal Clusters. Angew. Chem. Int. Ed. 2010, 49 (19), 3351-3355 https://doi.org/10.1002/anie.201000325.

(26) Molard, Y. Clustomesogens: Liquid Crystalline Hybrid Nanomaterials Containing Functional Metal Nanoclusters. Acc. Chem. Res. 2016, 49 (8), 1514-1523. https://doi.org/10.1021/acs.accounts.6b00236.

(27) Cordier, S.; Molard, Y.; Brylev, K. A.; Mironov, Y. V.; Grasset, F.; Fabre, B.; Naumov, N. G. Advances in the Engineering of Near Infrared Emitting Liquid Crystals and Copolymers, Extended Porous Frameworks, Theranostic Tools and Molecular Junctions Using Tailored Re6 Cluster Building Blocks. J. Clust. Sci. 2015, 26 (1), 53-81. https://doi.org/10.1007/s10876-014-0734-0.

(28) Molard, Y.; Ledneva, A.; Amela-Cortes, M.; Cîrcu, V.; Naumov, N. G.; Mériadec, C.; Artzner, F.; Cordier, S. Ionically Self-Assembled Clustomesogen with Switchable Magnetic/Luminescence Properties Containing $[\operatorname{Re} 6 \mathrm{Se} 8(\mathrm{CN}) 6] \mathrm{N}-(\mathrm{n}=3,4)$ Anionic Clusters. Chem. Mater. 2011, $23 \quad$ (23), 5122-5130. https://doi.org/10.1021/cm201589d.

(29) Cordier, S.; Fabre, B.; Molard, Y.; Fadjie-Djomkam, A.-B.; Tournerie, N.; Ledneva, A.; Naumov, N. G.; Moreac, A.; Turban, P.; Tricot, S.; et al. Covalent Anchoring of Re6Sei8 Cluster Cores Monolayers on Modified N- and p-Type Si(111) Surfaces: Effect of Coverage on Electronic Properties. J. Phys. Chem. C 2010, 114 (43), 18622-18633. https://doi.org/10.1021/jp1071007.

(30) Carlsson, S.; Zorina, L.; Allan, D. R.; Attfield, J. P.; Canadell, E.; Batail, P. Robust Dirac-Cone Band Structure in the Molecular Kagome Compound (EDT-TTFCONH2)6[Re6Se8(CN)6]. Inorg. Chem. 2013, 52 (6), 33263333. https://doi.org/10.1021/ic302790m.

(31) Efremova, O. A.; Brylev, K. A.; Kozlova, O.; White, M. S.; Shestopalov, M. A.; Kitamura, N.; Mironov, Y. V.; Bauer, S.; Sutherland, A. J. Polymerisable Octahedral Rhenium Cluster Complexes as Precursors for Photo/Electroluminescent Polymers. J. Mater. Chem. C 2014, 2 (40), 8630-8638. https://doi.org/10.1039/C4TC01643B.
(32)

Litvinova, Y. M.; Gayfulin, Y. M.; Kovalenko, K. A.; Samsonenko, D. G.; van Leusen, J.; Korolkov, I. V.; Fedin, V. P.; Mironov, Y. V. Multifunctional Metal-Organic Frameworks Based on Redox-Active Rhenium Octahedral Clusters. Inorg. Chem. 2018, 57 (4), 2072-2084. https://doi.org/10.1021/acs.inorgchem.7b02974.

(33) Gao, L.; Peay, M. A.; Gray, T. G. Encapsulation of Phosphine-Terminated Rhenium(III) Chalcogenide Clusters in Silica Nanoparticles. Chem. Mater. 2010, 22 (23), 6240 6245. https://doi.org/10.1021/cm101609p.

(34) Shestopalov, M. A.; Zubareva, K. E.; Khripko, O. P.; Khripko, Y. I.; Solovieva, A. O.; Kuratieva, N. V.; Mironov, Y. V.; Kitamura, N.; Fedorov, V. E.; Brylev, K. A. The First Water-Soluble Hexarhenium Cluster Complexes with a Heterocyclic Ligand Environment: Synthesis, Luminescence, and Biological Properties. Inorg. Chem. 2014, 53 (17), 9006-9013. https://doi.org/10.1021/ic500553v.

(35) Solovieva, A. O.; Kirakci, K.; Ivanov, A. A.; Kubát, P.; Pozmogova, T. N.; Miroshnichenko, S. M.; Vorontsova, E. V.; Chechushkov, A. V.; Trifonova, K. E.; Fufaeva, M. S.; et al. Singlet Oxygen Production and Biological Activity of Hexanuclear Chalcocyanide Rhenium Cluster Complexes $[\{\operatorname{Re} 6 \mathrm{Q} 8\}(\mathrm{CN}) 6] 4-(\mathrm{Q}=\mathrm{S}, \mathrm{Se}, \mathrm{Te})$. Inorg. Chem. 2017, 56 (21), https://doi.org/10.1021/acs.inorgchem.7b02212.

(36) Imoto, H.; Naumov, N. G.; Virovets, A. V.; Saito, T.; Fedorov, V. E. Primitive Cubic Packing of Anions in Cs4[Re6Te8(CN)6] $\quad 2 \mathrm{H} 2 \mathrm{O}$ and $\mathrm{Ba} 2[\operatorname{Re} 6 \mathrm{Te} 8(\mathrm{CN}) 6]$ 12H2O Crystals. J. Struct. Chem. 1998, 39 (5), 720-727. https://doi.org/10.1007/BF02903545.

(37) Naumov, N. G.; Virovets, A. V.; Podberezskaya, N. V.; Fedorov, V. E. Synthesis and Crystal Structure of K4[Re6Se8(CN)6]·3.5H2O. J. Struct. Chem. 1997, 38 (5), 857-862. https://doi.org/10.1007/BF02763902.

(38) Dolomanov, O. V.; Bourhis, L. J.; Gildea, R. J.; Howard, J. a. K.; Puschmann, H. OLEX2: A Complete Structure Solution, Refinement and Analysis Program. J. Appl. Crystal$\begin{array}{lllll}\log r . & 2009, & 42 & \text { (2), 339-341. }\end{array}$ https://doi.org/10.1107/S0021889808042726.

(39) Sheldrick, G. M. SHELXT - Integrated Space-Group and Crystal-Structure Determination. Acta Crystallogr. Sect. Found. $\quad A d v$. 2015, $71 \quad$ (1), 3-8 https://doi.org/10.1107/S2053273314026370.

(40) Sheldrick, G. M. Crystal Structure Refinement with SHELXL. Acta Crystallogr. Sect. C Struct. Chem. 2015, 71 (1), 3-8. https://doi.org/10.1107/S2053229614024218.

(41) Rabanal-León, W. A.; Murillo-López, J. A.; PáezHernández, D.; Arratia-Pérez, R. Understanding the Influence of Terminal Ligands on the Electronic Structure and Bonding Nature in [Re6(M3-Q8)]2+ Clusters. J. Phys. Chem. A 2014, 118 (46), 11083-11089. https://doi.org/10.1021/jp508892r.

(42) Matsue, T.; Evans, D. H.; Osa, T.; Kobayashi, N. ElectronTransfer Reactions Associated with Host-Guest Complexation. Oxidation of Ferrocenecarboxylic Acid in the Presence of .Beta.-Cyclodextrin. J. Am. Chem. Soc. 1985, 107 (12), 3411-3417. https://doi.org/10.1021/ja00298a003.

(43) Wang, Y.; Mendoza, S.; Kaifer, A. E. Electrochemical Reduction of Cobaltocenium in the Presence of $\beta$ Cyclodextrin. Inorg. Chem. 1998, 37 (2), 317-320. https://doi.org/10.1021/ic970702y.

(44) Jeon, W. S.; Moon, K.; Park, S. H.; Chun, H.; Ko, Y. H.; Lee, J. Y.; Lee, E. S.; Samal, S.; Selvapalam, N.; Rekharsky, M. V.; et al. Complexation of Ferrocene Derivatives by the Cucurbit[7]Uril Host: A Comparative Study of the Cucurbituril and Cyclodextrin Host Families. J. Am. Chem. Soc. 2005, $127 \quad$ (37), 12984-12989. https://doi.org/10.1021/ja052912c.

(45) Cramer, F.; Saenger, W.; Spatz, H.-C. Inclusion Compounds. XIX.1a The Formation of Inclusion Compounds of $\alpha$ Cyclodextrin in Aqueous Solutions. Thermodynamics and 
Kinetics. J. Am. Chem. Soc. 1967, 89 (1), 14-20. https://doi.org/10.1021/ja00977a003.

(46) Gelb, R. I.; Schwartz, L. M.; Radeos, M.; Laufer, D. A. Cycloamylose Complexation of Inorganic Anions. J. Phys. Chem. 1983, $87 \quad$ (17), 3349-3354. https://doi.org/10.1021/j100240a033.

(47) Yamashoji, Y.; Fujiwara, M.; Matsushita, T.; Tanaka, M. Evaluation of Association between Cyclodextrins and Various Inorganic Anions in Aqueous Solutions by 81Br NMR Spectroscopy. Chem. Lett. 1993, 22 (6), 1029-1032. https://doi.org/10.1246/cl.1993.1029.

(48) Godínez, L. A.; Schulze-fiehn, B. G.; Patel, S.; Criss, C. M.; Evanseck, J. D.; Kaifer, A. E. Observation and Interpretation of Anomalous Inorganic Anion Binding with $\alpha-$ and $\beta-$ Cyclodextrins in Aqueous Media. Supramol. Chem. 1996, 8 (1), 17-22. https://doi.org/10.1080/10610279608233964.

(49) Taraszewska, J.; Wójcik, J. Complexation of Inorganic Anions by $\beta$-Cyclodextrin Studied by Polarography and $1 \mathrm{H}$ NMR. Supramol. Chem. 1993, 2 (4), 337-343. https://doi.org/10.1080/10610279308029828.

(50) Schalley, C. A.; Castellano, R. K.; Brody, M. S.; Rudkevich, D. M.; Siuzdak, G.; Rebek, J. Investigating Molecular Recognition by Mass Spectrometry: Characterization of Calixarene-Based Self-Assembling Capsule Hosts with Charged Guests. J. Am. Chem. Soc. 1999, 121 (19), 45684579. https://doi.org/10.1021/ja990276a.
(51) Di Tullio, A.; Reale, S.; De Angelis, F. Molecular Recognition by Mass Spectrometry. J. Mass Spectrom. JMS 2005, 40 (7), 845-865. https://doi.org/10.1002/jms.896.

(52) Zhang, B.; Guan, W.; Yin, F.; Wang, J.; Li, B.; Wu, L. Induced Chirality and Reversal of Phosphomolybdate Cluster via Modulating Its Interaction with Cyclodextrins. Dalton Trans. 2018, 47 (5), $1388-1392$. https://doi.org/10.1039/C7DT03669H.

(53) Zhang, B.; Yue, L.; Wang, Y.; Yang, Y.; Wu, L. A Novel Single-Side Azobenzene-Grafted Anderson-Type Polyoxometalate for Recognition-Induced Chiral Migration. Chem. Commun. 2014, 50 (74), 10823-10826. https://doi.org/10.1039/C4CC04442H

(54) Attoui, M.; Pouget, E.; Oda, R.; Talaga, D.; Le Bourdon, G.; Buffeteau, T.; Nlate, S. Optically Active PolyoxometalateBased Silica Nanohelices: Induced Chirality from Inorganic Nanohelices to Achiral POM Clusters. Chem. - Eur. J. 2018, 24
https://doi.org/10.1002/chem.201801905.

(55) Tedesco, D.; Bertucci, C. Induced Circular Dichroism as a Tool to Investigate the Binding of Drugs to Carrier Proteins: Classic Approaches and New Trends. J. Pharm. Biomed. Anal. 2015, 113, 34-42. https://doi.org/10.1016/j.jpba.2015.02.024. 


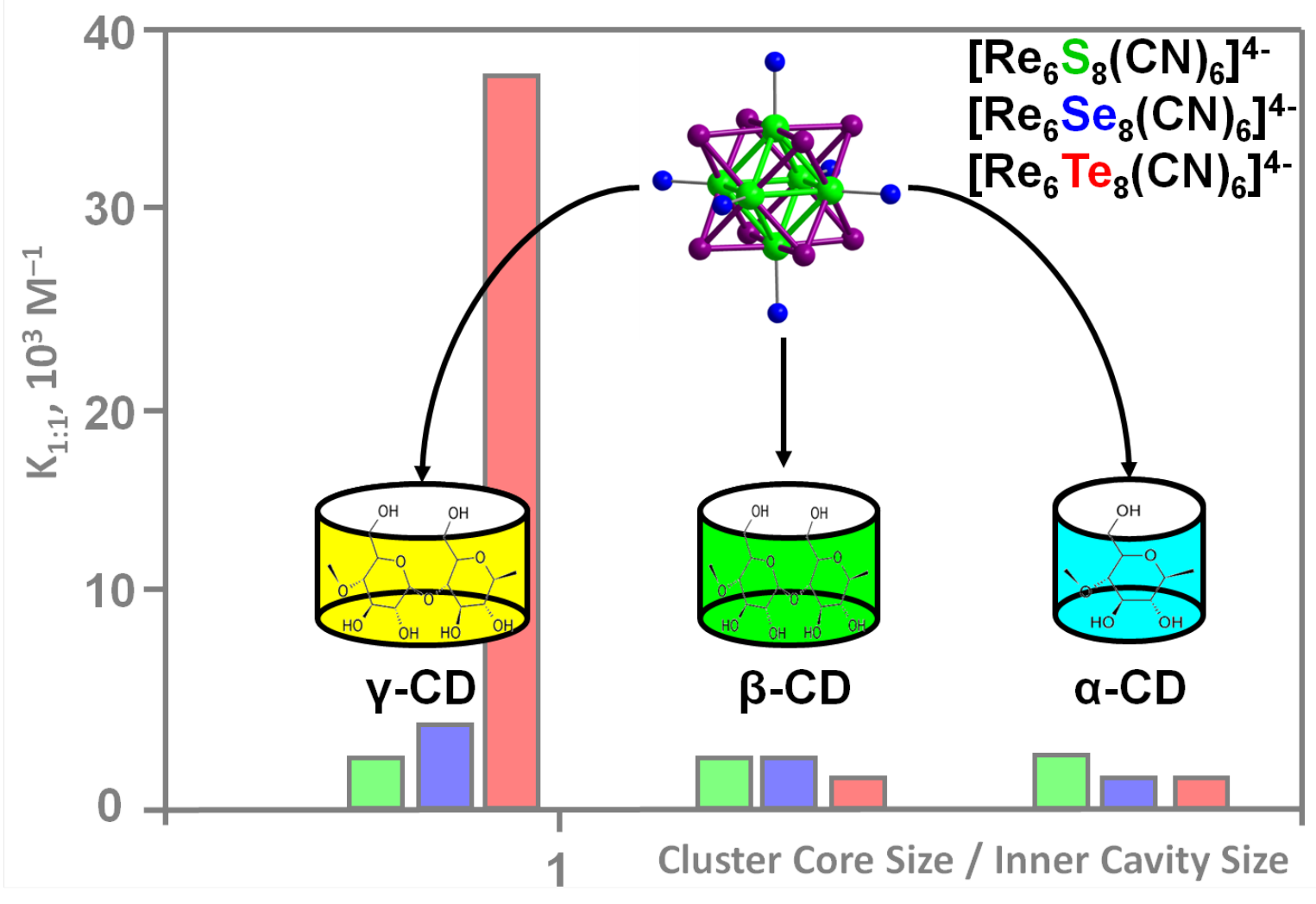

